\title{
Rural Electrification and Household Labor Supply: Evidence from Nigeria
}

\author{
Claire Salmon* $\quad$ Jeremy Tanguy ${ }^{\dagger}$
}

\begin{abstract}
In Nigeria, the most populated African country, rural electrification is a critical issue because of the low household electrification rate and the poor quality of the grid. This energy poverty has harmful economic and social consequences in rural areas, such as low productivity, lack of income-generating opportunities and poor housing conditions. In this paper, we consider electrification as a technical shock that may affect household time allocation. Using the 2010-2011 General Household Survey, we investigate how electrification affects female and male labor supply decisions within rural households in Nigeria. Focusing on husband-wife data, we consider potential dependence in spouses' labor supply decisions and address the challenge of zero hours of work using a recent copula-based bivariate hurdle model (Deb et al. 2013). In addition, an instrumental variable strategy helps identify the causal effect of electrification. Our results underline that this dependence in spouses' labor supply decisions is critical to consider when assessing the impact of electrification on these outcomes. Electrification increases the working time of both spouses in the separate assessments, but the joint analysis emphasizes only a positive effect of electrification on husbands' working time. In line with the household labor supply approach, our findings highlight that, within the household, the labor supply decisions of one spouse significantly affect those of the other spouse. Thus, if we neglect the effect of electrification on the spouse of the individual examined, we may fail to assess how this individual has been actually affected by this common shock on both spouses. Our results suggest that these within-household relationships promote husbands' working time at the expense of wives' working time.
\end{abstract}

Keywords: rural electrification, labor supply, developing countries, joint decision making, bivariate hurdle model, copulas

JEL Classification: C3, C31, C35, D1, J22, O13

*IREGE, University Savoie Mont Blanc. E-mail: claire.salmon@univ-savoie.fr. Address: IAE Savoie Mont Blanc, 4 Chemin de Bellevue, BP 80 439, 74944 Annecy-le-Vieux Cedex, France.

${ }^{\dagger}$ GAINS-TEPP, University of Le Mans. E-mail: jeremy.tanguy@univ-lemans.fr. Address: Université du Maine, UFR Droit Economie Gestion, Avenue Olivier Messiaen, 72085 Le Mans Cedex 9, France. 


\section{Introduction}

Electrification is an important challenge for economic and social development in developing countries and especially in Africa, which has the lowest electrification rate in the world. In Nigeria, the most populated African country, rural electrification is a critical issue because of the low household electrification rate and the poor quality of the grid. In 2015, only half of the whole population and one-third of the rural population had electricity. Even when connected to the grid, most urban households experience blackouts every day and most rural households have only a few hours of electricity per day (Aliyu et al. 2013). This energy poverty has harmful economic and social consequences in rural Nigeria. Firms using electrical capital goods can not locate in non-connected areas, which limits income-generating activities for the rural population and increases both underemployment and poverty. An inadequate supply of electricity is considered by both households and entrepreneurs as a major constraint to improving welfare and developing business (ADB 2009). As a consequence, many rural households migrate to cities and firms are concentrated in connected areas.

In the literature, electricity consumption is widely presented as a growth factor (see Ozturk 2010; Payne 2010). According to the electricity-led growth hypothesis, policymakers could boost productivity and growth by expanding electricity supply. In Nigeria, Iyke (2015) shows that electricity consumption is a fundamental driver of economic growth, which can contribute to enhanced societal welfare through job creation and poverty alleviation. A recent strain of empirical literature focuses on the microeconomic consequences of electrification on the labor market in developing countries. Most studies highlight that (rural) electrification positively affects labor supply especially of women, who are encouraged to move away from domestic work and participate in the labor market. In South Africa, Dinkelman (2011) shows that rural electrification significantly increases female employment but has no effect on male employment. Grogan and Sadanand $(2009,2013)$ and Grogan $(2012)$ outline a similar increase in female employment following household electrification in Nicaragua, Guatemala and Colombia, respectively. In Bangladesh, Chowdhury (2010) also shows that electrification increases the employment probability of women while it simultaneously decreases the total time that women spend on unpaid work. In rural Peru, Dasso and Fernandez (2015) show that electrification has different effects on the employment de- 
cisions of men and women - men are less likely to have a second job, whereas women are more likely to participate in the workforce, especially as self-employed - but a common positive effect on their working time.

Following this emerging strain of literature, we propose to assess, for the first time, the impact of electrification on male and female labor supply in Nigeria, where rural electrification is a critical issue. We contribute to the extant literature by addressing two empirical shortcomings of previous studies. First, these studies rely on the implicit but questionable assumption that males and females make their labor supply decisions independently within the household. The majority of the empirical studies in the household labor supply literature (Chiappori 1988, 1992) considers that male and female working time should be analyzed jointly amongst married couples (Huffman and Lange 1989; Zhang 2014). Second, some authors identify a causal effect of electrification on employment probability but fail to specify the effect on working time. For this purpose, we rely on matched husband-wife data from the 2010-2011 General Household Survey (GHS) and analyze spouses' labor supply outcomes simultaneously, in the form of participation and time allocation in the labor market, using the bivariate hurdle model proposed by Deb et al. (2013). We identify the causal effect of electrification on both labor supply outcomes using an instrumental variable strategy.

The rest of this paper proceeds as follows: Section 2 discusses the effects of household electrification on employment in rural areas. Section 3 describes the context of electrification in Nigeria. Section 4 describes the Nigerian household survey data, as well as the data processing and summary statistics. Section 5 outlines the different econometric specifications. In Section 6 we examine the effects of household electrification on husbands' and wives' labor supply, first separately and then jointly. Section 7 concludes.

\section{Expected effects of electrification on employment}

Electrification induces changes in the nature and the amount of work done by households both at home and in the market. Electricity provision can be interpreted as a technical shock that can affect labor outcomes through different channels. Figure 1 proposes a synthetic view of the channels that have been identified in the literature (Akpan et al. 2013; Dinkelman 2011; Kanagawa 
and Nakata 2008; Rao 2013). Individuals' labor outcomes depend on both their labor supply and firms' labor demand. Thus, for a comprehensive understanding of how electrification may affect labor outcomes, we have to consider its effects on both sides of the labor market.

Figure 1. Expected effects of electrification on employment

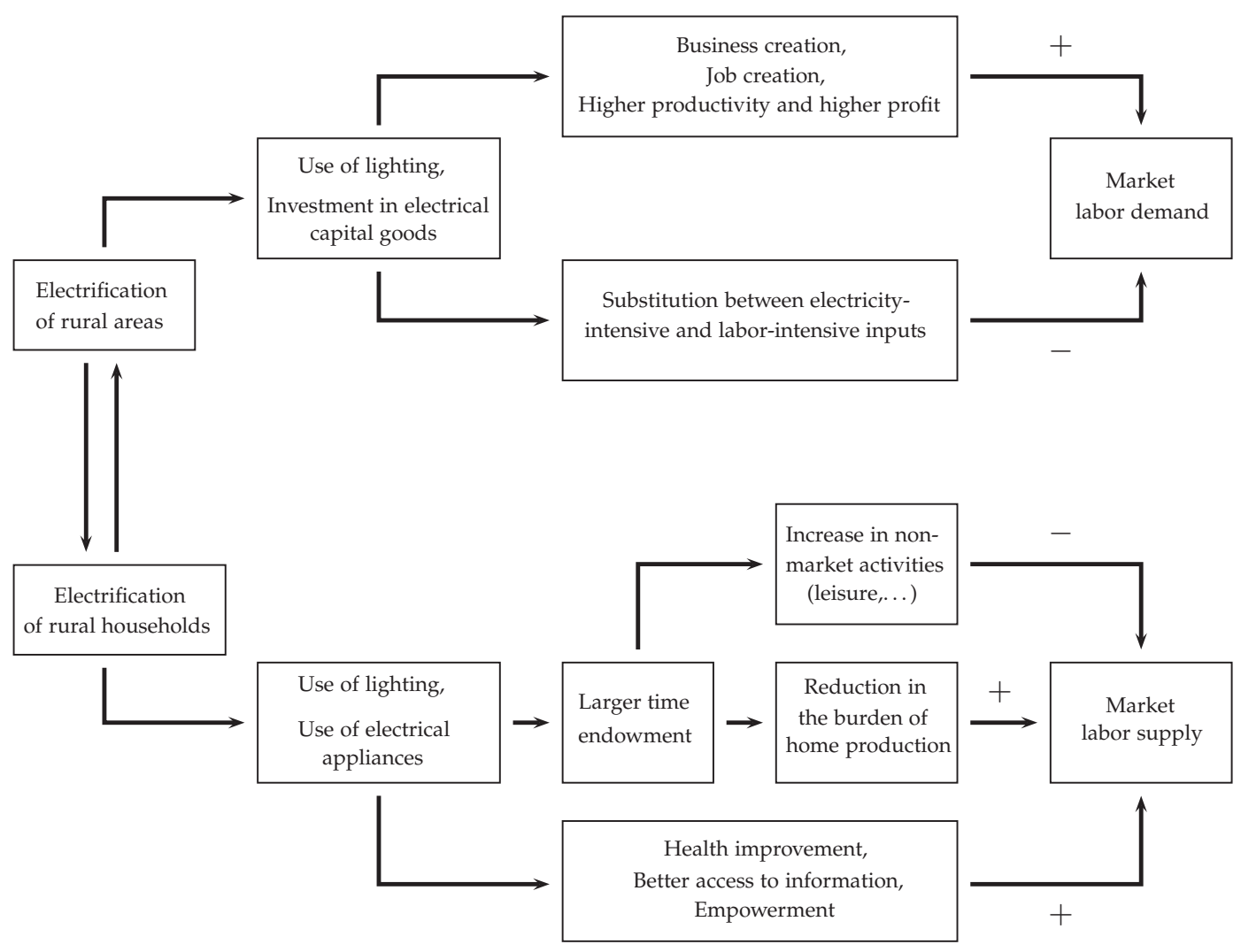

On the demand side, rural electrification may have a positive effect by fostering business creation, job creation and sectoral diversification of activities. In addition, connected firms are expected to be more productive, potentially increasing wages and profits. In contrast, rural electrification may also cause a decrease in labor demand by causing electricity-intensive inputs to be substituted for labor-intensive inputs. The labor demand increase is not necessarily the same for women and men, assuming they do not specialize in the same occupations. For instance, it could be relatively higher for women in an area that develops textile manufacturing, because this sector is generally more intensive in female-labor input.

On the supply side, electrification may have a positive effect mainly through an increase in the household time endowment. Electrification enables people to save time on domestic chores or 
provides them additional time each day. Lighting is the primary use of electricity in rural households (Kohlin et al. 2011), which enables households to extend the day, and thereby the potential working day, with artificial light. Electrification might also enable households to increase the efficiency of domestic chores (e.g., cooking, water and fuelwood collection, laundry, childcare) through the use of electrical appliances (e.g., cooker, sewing machine, water pump, refrigerator). This release of domestic time provides people with an opportunity to increase the time devoted to the labor market or simply to start working. Because domestic chores are mainly carried out by women, their labor supply might seemingly be more powerfully impacted by electrification than that of men. This relationship is neither guaranteed nor trivial. First, it relies on the actual use of electrical appliances and therefore the household's investment in such appliances. Bernard (2010) shows that electricity is often a complement to, rather than a substitute for, traditional fuels in sub-Saharan Africa. Thus rural electrified households often continue to use fuelwood to prepare meals in this region. The unreliability of electricity provision in most African rural areas does not encourage households to radically change their cooking process and their fuel uses. A good quality of the grid is therefore a prerequisite to any structural change. Second, even if electrification enables households to save time, their members may decide to devote this extra time to leisure or to more productive and time-intensive home-based activities rather than to the labor market.

Electricity may also have indirect effects on labor supply via its positive externalities for health and safety. Once electrified, households can decrease their consumption of candles or kerosene lamps and thereby reduce indoor air pollution, as well as accident and fire risks. Röllin et al. (2004) show that rural electrified households in South Africa have significantly less indoor air pollution than their non-electrified counterparts. Also in South Africa, Spalding-Fecher and Matibe (2003) emphasize the strong positive health externalities of electrification, due to the substantial decrease in the use of "dirty" fuels, such as coal, firewood and paraffin. By providing better access to television and information and communication technologies (ICT), electrification may contribute to the empowerment, especially of women (Duflo 2012). Better access to media tends to improve people's knowledge about important issues, such as health, education and women's rights. In Nepal, Dahal (2013) finds that the availability of a community radio has a significant role in the socialization process of women, which is a first step in empowerment. More generally, the development of ICT in households enhances the position of women in society and the labor 
market, as discussed by Shirazi (2012) and Bullough et al. (2012). These long-term effects can progressively change the nature and the amount of women's market work.

It is noteworthy that effects of electrification on labor supply and labor demand, as depicted in Figure 1, are only effective if the quality of service is good. Chronic and persistent outages prevent or limit the expected effects. This is an important point in the Nigerian context.

\section{Context: The Nigerian electricity crisis}

Electricity generation in Nigeria started in 1896, in Lagos. In 1972, the National Electric Power Authority (NEPA) was created, a company with an exclusive monopoly over electricity generation, transmission, distribution and sales. Given the resource endowment of the country, power generation has been mainly developed by thermal plants and hydro power plants, which still contribute about $60 \%$ and $30 \%$ of electricity supply respectively (Barros et al. 2014).

In spite of its early development and its strategic importance for economic development, the electrification of Nigeria has been very slow and electricity demand is at present far higher than supply. About $30 \%$ of the rural population is connected, compared with $60 \%$ of the urban population. Oseni (2012) shows that the electrification rate has even decreased over the past decade, because the Nigerian population has grown faster than the electricity supply. At 156 kWh in 2011-2015, electricity consumption per capita is one of the lowest rates in the world. In comparison, electricity consumption per capita has reached 1,591 kWh in Namibia, 4,405 kWh in South Africa and 2,462 kWh in Brazil (World Bank 2015).

The poor quality of the electrical grid is also a critical issue in Nigeria (Barros et al. 2014).

The majority of urban households experience blackouts every day. A study conducted in rural areas reveals that when grid power is available, it is highly erratic: power is generally available less than 4 hours per day (Olatomiwa et al. 2015). This deficient situation can be explained by several causes: underinvestment in transmission and distribution networks, obsolete installations, inefficient use of capacity, high system losses, technical constraints, vandalism and corruption.

The current low electrification in Nigeria creates serious constraints to economic activities. In a survey conducted in the manufacturing sector, $82 \%$ of respondents rank electricity as their major problem (Adenikinju 2003). Most firms admit that energy constraints have influenced their 
location choice, input combination and type of business. For instance, $66 \%$ recognize that they make their employees work longer to compensate for time lost due to outages. In rural areas, the absence or weakness of electrical connections strongly limits sectoral diversification. Most households work in agriculture, which is less electricity-dependent than other sectors. Households and firms are constrained to use non-electrical capital goods, which are generally weakly efficient. In fact, to have electricity, firms generally have to invest in expensive self-generating systems (Akpan et al. 2013). As a consequence, many rural entrepreneurs migrate to cities and firms locate almost exclusively in electrified areas.

Various measures have been taken to address the electricity problems in Nigeria. In 2000, the government restructured the power sector by encouraging private participation. In September 2013, the Power Holding Company of Nigeria (PHCN), formerly NEPA, was privatized, leading to the creation of 18 successor firms: 11 for electricity distribution, 6 for power generation, and 1 for transmission. More recently, two plans were developed by the Nigerian government (the Renewable Energy Master Plan and the Vision 20:2020 agenda) to define a new energy policy. These plans suggest the development of a grid extension program to rural areas; diversification of energy sources, including renewable energy resources such as solar, wind and biomass, for power generation; and the development of a more decentralized hybrid microgrid system. Recent technical studies have dealt with the potential costs and benefits of these plans to boost the electricity supply system in this country, particularly in rural areas (see Ajayi and Ajayi 2013; Aliyu et al. 2013; Barros et al. 2014; Dada 2014; Ohiare 2015; Oseni 2011; Shaaban and Petinrin 2014).

\section{Data and variables}

\subsection{General Household Survey (GHS) data}

We mainly rely on the General Household Survey (GHS) conducted by the Nigerian government. In Nigeria, the GHS is the analogous to the Living Standards Measurement Survey (LSMS) of the World Bank in terms of variable coverage. In its standard form, the survey is conducted yearly, with data collected from randomly selected households all over the country during the four quarters of the year. A drawback of this survey is that different households are surveyed in 
each survey year. However, 2010-2011 marked the start of the GHS Panel, which aimed to survey the same households in subsequent editions.

We use 2010-2011 as our survey period, obtaining data for an initial sample of 28075 people from 4878 households. Unlike the standard, annual GHS, the GHS-Panel is carried out every two years. The 2010-2011 edition consisted of a post-planting visit in August-October 2010 and a post-harvest visit in February-April 2011. We specifically use data from the post-harvest visit, during which the data on energy issues were gathered. Our focus is on the effect of electrification on the labor supply in rural households, representing approximately $70 \%$ of the initial sample, or 3326 rural households and 20155 individuals.

To test dependence between spouses' labor supply decisions within the household, we investigate husband-wife pairs. After excluding husband-wife observations for which one or both spouses report a missing value for at least one of our variables of interest, we obtained a sample of 2720 husband-wife pairs, or 5440 individuals. Unlike previous studies (e.g., Abdulai and Delgado 1999), we only consider monogamous households in our empirical analysis, thereby reducing the sample further to 2033 husband-wife pairs. Among these households, some consist of multiple monogamous pairs, such as pairs formed by the parents or children of the main pair in the household. To limit any potential bias, we focused on households composed of only one monogamous pair, which restricted the sample to 1996 households. Finally, we decided to limit our analysis to adults of working age and thus retained husbands and wives aged 20 to 75 years. This age restriction is consistent with previous literature (e.g., Grogan and Sadanand 2013) and can be easily justified on the basis of workers' age structure in the sample (see Figure 2). Ultimately, we thus study a sample of 1819 husband-wife pairs.

\subsection{Variables of interest}

The variables of interest are defined in accordance with the purpose of the paper, namely, to assess the impact of household electrification on spouses' labor supply.

\section{Household electrification}

Following previous studies (e.g., Grogan and Sadanand 2013), we assess household electrification using a dummy variable that is equal to 1 if the household is electrified and reports 
Figure 2. Age structure of workers in monogamous couples
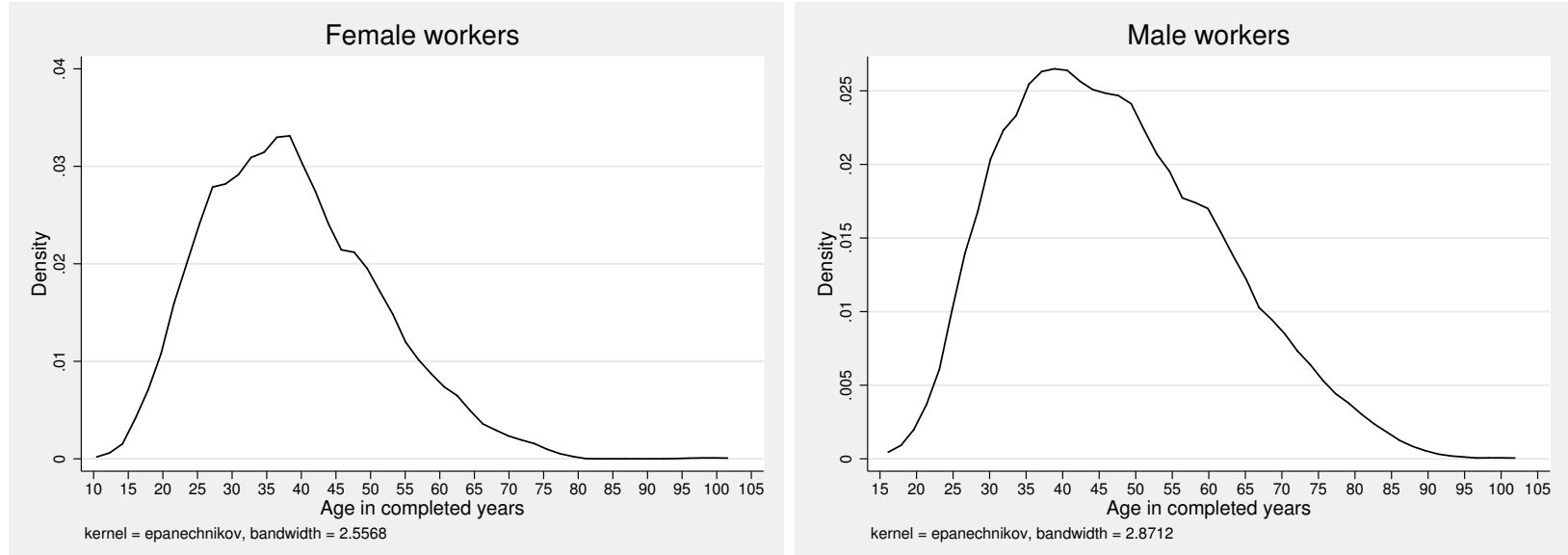

using electricity during the week preceding the survey, and 0 otherwise. $84 \%$ of electrified households are connected via PHCN. Other sources of electricity supply include different types of generator. In Table 4, we find that $33.7 \%$ of households in our sample have electricity access. It is important to point out at this stage that the electricity supply of the corresponding households is not necessarily continuous. In fact, as outlined in Table 1, most connected households face regular blackouts. In Table 2, we see that domestic equipment rates in electrical appliances are low amongst all households, connected or non-connected. However, connected households are significantly more equipped than non-connected households. This table suggests that after electrification the equipment rates significantly increase in appliances linked to information and communication technologies (e.g., TV sets and DVD players), and food preparation and storage (stove, fridge and freezer), and laundry care (sewing machine and iron).

Table 1. Blackout frequency in rural connected households

\begin{tabular}{lcc}
\hline \hline & Obs. & $\%$ \\
\hline Every day & 326 & 54.42 \\
Several times a week & 157 & 26.21 \\
Several times a month & 67 & 11.19 \\
Several times a year & 30 & 5.01 \\
Never & 19 & 3.17 \\
\hline Total & 599 & 100 \\
\hline \hline
\end{tabular}

Notes: The data source is the Nigeria 2010-2011 General Household Survey - Panel. Only electrified monogamous households with spouses aged between 20 and 75 are considered. 
Table 2. Equipment rates among connected and non-connected households

\begin{tabular}{lccc}
\hline \hline & No electricity & Electricity & $p$-value \\
\hline Sewing machine & 0.070 & 0.175 & 0.000 \\
Gas cooker & 0.006 & 0.051 & 0.000 \\
Stove (electric) & 0.003 & 0.060 & 0.000 \\
Stove gas (table) & 0.005 & 0.039 & 0.000 \\
Stove (kerosene) & 0.192 & 0.535 & 0.000 \\
Fridge & 0.024 & 0.232 & 0.000 \\
Freezer & 0.008 & 0.101 & 0.000 \\
Fan & 0.093 & 0.582 & 0.000 \\
Radio & 0.523 & 0.662 & 0.000 \\
Iron & 0.206 & 0.506 & 0.000 \\
TV set & 0.105 & 0.602 & 0.000 \\
Computer & 0.010 & 0.038 & 0.000 \\
DVD player & 0.080 & 0.423 & 0.000 \\
Satellite dish & 0.016 & 0.075 & 0.000 \\
\hline \hline
\end{tabular}

Notes: The data source is the Nigeria 2010-2011 General Household Survey -

Panel. Only electrified monogamous households with spouses aged between 20 and 75 are considered.

\section{Working time of spouses}

The labor supply analysis is based on weekly hours of work, recorded for each spouse over the week preceding the survey. The distribution of positive hours of work is reported in Figure 3 for both husbands and wives from the restricted sample of monogamous pairs. As we show in Table 4, a large proportion of husbands and wives report zero hours of work during the previous week - more than $10 \%$ of husbands and approximately $30 \%$ of wives. We take into account the hours spent doing three types of work indicated in the survey: (i) work for someone who is not a member of the household (e.g. enterprise, company, government or any other individual), (ii) work on a farm owned or rented by a member of the household (cultivating crops or other farming tasks, caring for livestock), (iii) work on her own account or in a business enterprise belonging to her or someone in the household (e.g. trader, shop-keeper, barber, dressmaker, carpenter, taxi driver). These hours of work correspond to jobs in different sectors: agriculture, mining, manufacturing, buying and selling, financial services, personal services, education or health, and public administration. We report in Table 3 the distribution of working husbands and wives in these different sectors, differentiating between connected and non-connected households. We note that 
agriculture and mining have a substantial weight in the employment of the rural households in our sample, especially in non-connected households and among husbands. We also underline that wives' jobs are more sectorally diversified than mens' are, with a relatively higher weight in buying and selling, financial services and manufacturing.

Figure 3. Weekly hours of work among workers in monogamous couples
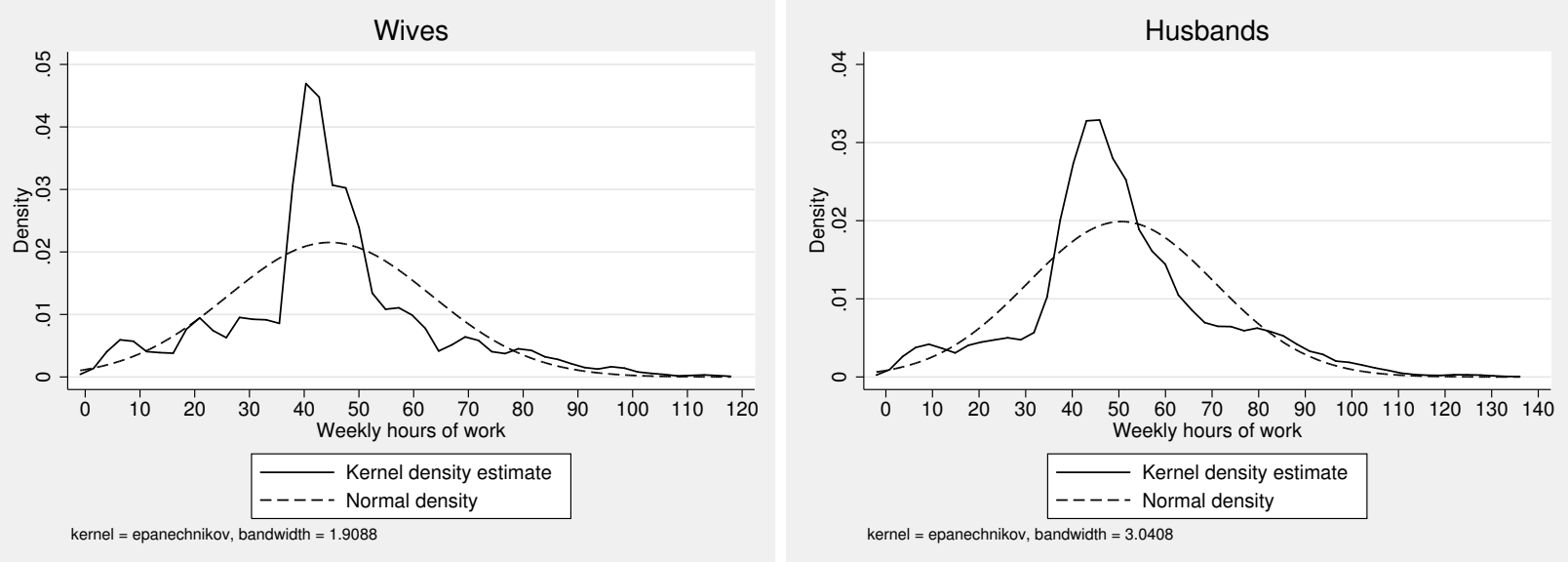

Table 3. Sectoral distribution of workers according to electrification status

\begin{tabular}{|c|c|c|c|c|c|c|}
\hline & \multicolumn{3}{|c|}{ Husbands } & \multicolumn{3}{|c|}{ Wives } \\
\hline & No electricity & Electricity & $p$-value & No electricity & Electricity & $p$-value \\
\hline Agriculture or mining & 0.763 & 0.415 & 0.000 & 0.567 & 0.368 & 0.000 \\
\hline Manufacturing & 0.015 & 0.024 & 0.203 & 0.117 & 0.051 & 0.000 \\
\hline $\begin{array}{l}\text { Buying and selling, } \\
\text { financial services }\end{array}$ & 0.060 & 0.129 & 0.000 & 0.199 & 0.360 & 0.000 \\
\hline Personal services & 0.032 & 0.078 & 0.000 & 0.063 & 0.071 & 0.572 \\
\hline Education or health & 0.031 & 0.080 & 0.000 & 0.016 & 0.094 & 0.000 \\
\hline Public administration & 0.028 & 0.082 & 0.000 & 0.010 & 0.039 & 0.000 \\
\hline Observations & 1078 & 549 & & 831 & 467 & \\
\hline
\end{tabular}

Notes: The data source is the Nigeria 2010-2011 General Household Survey - Panel. Only husbands and wives from monogamous households, aged between 20 and 75 years, are considered.

\subsection{Control variables}

To our knowledge, the relationship between electrification and household labor supply in Nigeria has not been studied previously. A few studies have investigated the determinants of household labor supply in Nigeria (Aminu 2010; Anugwom 2009; Fadayomi and Ogunrinola 
Table 4. Variable definitions and descriptive statistics

\begin{tabular}{|c|c|c|c|c|c|}
\hline Variable name & Definition & Mean & Std. Dev. & Min & Max \\
\hline \multicolumn{6}{|c|}{ Individual / household characteristics } \\
\hline age $_{h}$ & Husband's age, in years & 47.343 & 12.926 & 21 & 75 \\
\hline $\operatorname{age}_{\mathrm{w}}$ & Wife's age, in years & 36.821 & 10.931 & 20 & 71 \\
\hline educ $_{h}$ & Husband's years of education & 5.383 & 5.364 & 0 & 17 \\
\hline $\operatorname{educ}_{w}$ & Wife's years of education & 4.169 & 4.842 & 0 & 16 \\
\hline christian & Christian religion & 0.553 & - & 0 & 1 \\
\hline muslim & Muslim religion & 0.424 & - & 0 & 1 \\
\hline kids06 & Number of children under age 6 & 1.450 & 1.405 & 0 & 10 \\
\hline kids612 & Number of children aged 6-12 & 1.153 & 1.073 & 0 & 5 \\
\hline kids1218 & Number of children aged $12-18$ & 0.816 & 0.995 & 0 & 5 \\
\hline adults & Number of adults (age $\geqslant 18$ ) & 2.811 & 1.233 & 2 & 11 \\
\hline assets / head & $\begin{array}{l}\text { Value of assets per household head, in Naira. Assets in- } \\
\text { clude all household (e.g., bed, computer, bicycle) and agri- } \\
\text { cultural assets. }\end{array}$ & 14047.12 & 54555.54 & 0 & 1546025 \\
\hline electricity & Electricity is working in the dwelling & 0.337 & - & 0 & 1 \\
\hline \multicolumn{6}{|c|}{ Regional characteristics } \\
\hline rural unempl. & $\begin{array}{l}\text { Unemployment rate in rural areas at the state level (2006 } \\
\text { Census) }\end{array}$ & 0.138 & 0.092 & 0.0001 & 0.461 \\
\hline$\%$ urban & $\begin{array}{l}\text { Fraction of the LGA population living in urban areas in } \\
2011 .\end{array}$ & 0.036 & 0.140 & 0 & 0.848 \\
\hline \multicolumn{6}{|c|}{ Dependent variables } \\
\hline$d_{h}$ & $=1$ if husband participates in work & 0.894 & - & 0 & 1 \\
\hline$d_{w}$ & $=1$ if wife participates in work & 0.714 & - & 0 & 1 \\
\hline$y_{h}$ & Total husband hours allocated to work & 45.222 & 24.523 & 0 & 133 \\
\hline$y_{w}$ & Total wife hours allocated to work & 31.898 & 25.571 & & \\
\hline \multicolumn{6}{|c|}{ Instrumental variables } \\
\hline pop. density & $\begin{array}{l}\text { Population density in the LGA, measured as the ratio pop- } \\
\text { ulation / surface, using the } 2006 \text { Census }\end{array}$ & 323.345 & 471.771 & 0.048 & 4063.502 \\
\hline $\mathrm{km}$ to road & Household distance to nearest major road, in kilometers & 18.014 & 19.296 & 0 & 115.2 \\
\hline Observations & & \multicolumn{2}{|c|}{1819} & & \\
\hline
\end{tabular}

Notes: The data source is the Nigeria 2010-2011 General Household Survey - Panel. Only individuals from monogamous households, aged between 20 and 75 years, are considered. LGA = local government area.

2013), so we rely on these studies and the growing literature devoted to the impact of electrification on household labor supply to select the appropriate control variables.

We first introduce some standard individual and household characteristics, including age, education, religion, and the number of children and adults (e.g., Abdulai and Delgado 1999; Huffman and Lange 1989; Tokle and Huffman 1991). Age is a proxy of general experience that 
increases the marginal value of time devoted to each activity (Abdulai and Delgado 1999); the squared value of age enables us to control for the nonlinear life cycle. Education is a proxy for potential productivity. Any increase in a person's education level increases her probability of participating in the labor market and devoting time to work, if it increases her opportunity costs for staying at home (Abdulai and Delgado 1999). The number of children in the household indicates the number of dependents and is particularly likely to determine wives' participation in the labor market. However, some empirical results in other developing countries demonstrate that child rearing and off-farm work are not necessarily competing activities, so the number of children might not have significant effects on spouses' time spent at work (e.g., Skoufias 1994). Finally, the number of adults in the household increases the household's capacity to diversify its income-generating activities, so it is likely to increase both participation in the labor market and time devoted to work (Matshe and Young 2004).

To control for the strength of the local labor market, we also include the unemployment rate among rural people in the state, derived from the 2006 Census, the latest in Nigeria. In a crosssectional study, this variable exhibits relatively little variation and is likely to pick up a location effect. There are more recent data on states' aggregate unemployment, provided by the National Bureau of Statistics, but only census data provide information on unemployment among rural people. The average unemployment rate of a given state may not reflect the labor market context in its rural areas, given the generally strong differences in employment between urban and rural areas. To control for household wealth and socioeconomic status, which likely determine both participation and time allocation decisions in the labor market, we also include the per capita value of household assets. In previous literature, household wealth has been proxied using the value of household productive assets (e.g., Matshe and Young 2004) or household possession of a water pipe and/or dirt floor (e.g., Grogan and Sadanand 2013). The variable definitions and descriptive statistics are in Table 4.

Finally, we control for location effects in all the regressions. Nigeria comprises 36 states and Abuja, the federal capital territory. ${ }^{1}$ These states in turn can be divided into 774 Local Government Areas (LGA). Although including LGA fixed effects in the econometric regressions

1. See Appendix D. 
would be valuable, because they refer to small geographic areas where local economic conditions are likely similar, introducing them also might be inefficient, given the small size of our sample. We therefore use state-level fixed effects instead.

\section{Econometric specifications}

To analyze household labor supply, we rely on time use data, which indicate the hours of work over the past week. Linear regression models are generally inappropriate for analyzing such data, due to the violation of the normality assumption that results from exact zeros and a right-skewed data distribution. ${ }^{2}$ Although linear regression models may be robust to violations of the normality assumption, the very right-skewed distribution of such data is likely to result in biased parameter estimates. ${ }^{3}$

Although the Tobit model often provides an adjustment for the zeros (e.g., Grogan and Sadanand 2013), it is deficient in interpreting the zero observations. In this model, a zero value corresponds to a corner solution in the utility maximization program, that is, an individual who is supposed to participate in the labor market but who chooses not to work at the current level of exogenous variables (e.g., economic incentives, wages). However, zero observations for working time might arise for other reasons too. First, some people may prefer not to participate in the labor market, due to personal preferences, inadequate qualifications or disabilities. Such scenarios imply abstention rather than a corner solution. Second, work may be undertaken on an infrequent basis only, and the survey might have been conducted at a time when no work was being sought. Thus, some zero observations may be sampling zeros, resulting because the reference period of the data is shorter than the period over which decisions are made, rather than corner solutions.

In coherence with its interpretation of zeros, the Tobit estimator is restrictive in assuming

2. The exact zeros represent a problem for standard regression models because no transformation can produce a normal distribution of the data: the zeros are just transformed to another value.

3. A linear regression model may well approximate the fitted values, especially those near the mean values of the independent variables, but may result in negative fitted values and negative predictions for the dependent variable when more extreme values of the independent variables are considered (Wooldridge 2012). 
that the process that generates variation in the censoring process is proportional to the process that generates variation in the distribution of the dependent variable, conditional on it being observed. When analyzing labor supply, the process determining the decision to participate in the labor market seemingly would be the same as the one that determines time allocated to work, such that they would be determined by the same variables. However, the factors that explain the participation decision in the labor market need not have the same effect on the time allocation decision in this activity. When the decisions turn out to be two very different processes, one is likely to have an endogenous participation problem. Dealing with this problem involves modeling two separate decisions: (i) whether or not to participate in the labor market, and (ii) the amount of time the participant allocates to work.

\subsection{Distinction of labor supply decisions: Participation and time allocation}

The double-hurdle model (Blundell et al. 1987; Cragg 1971) or two-part model offers a general approach to assessing participation in the labor market and time allocation to work as two separate decisions. It is a parametric generalization of the Tobit model, where the decision to participate in the labor market and the level of participation are determined by two separate stochastic processes. Heckman's (1979) sample selection model is also a candidate in such a context, but it remains restrictive, with the assumption that none of the zero observations may be due to a corner solution. ${ }^{4}$ In the double-hurdle model, a two-stage process must have been completed for us to observe positive hours of work: (1) the individual has decided to participate in the labor market, and (2) this individual has allocated some amount of time to work. Thus, we may observe no working time due to either of these two processes. The double-hurdle is very popular in labor supply analysis (e.g., Blundell et al. 1987; Matshe and Young 2004), and we specify it with two latent variables, $d_{j i}^{*}$ and $y_{j i}^{*}$, which refer to the labor market participation and time allocation decisions respectively, for spouse $j$ in household $i$ :

4. In Heckman's (1979) sample selection model, if a variable affects the number of work hours, it cannot sequentially lead to reduced and then zero work hours, though it may have that effect if it appears in the participation equation. 


$$
\begin{aligned}
& d_{j i}^{*}=\mathbf{Z}_{i}^{\prime} \gamma+\varepsilon_{i}, \quad \varepsilon_{i} \sim \mathcal{N}(0,1), \quad j=h, w, \quad \text { and } \\
& y_{j i}^{*}=\mathbf{X}_{i}^{\prime} \beta+u_{i}, \quad u_{i} \sim \mathcal{N}\left(0, \sigma^{2}\right), \quad j=h, w,
\end{aligned}
$$

where $u_{i}$ and $\varepsilon_{i}$ are independently distributed.

The original double-hurdle model assumes that residuals are normally distributed in the positive part, so that the positive values are modeled with a standard linear model, such as ordinary least squares (OLS). However, the maximum likelihood estimator of this model may be inconsistent when this normality assumption is violated (Arabmazar and Schmidt 1982). We test the normality assumption in residuals in several ways, using residual estimates from a truncated regression model. First, the Shapiro-Wilk $W$ test gives, for both husbands and wives, a very small $p$-value (0.000), indicating that we can reject the notion that the residuals are normally distributed. We also use graphs to offer some indications of the non-normality in residuals for both husbands and wives: a kernel density plot (Figure 4), a normal probability plot (Figure 5) and a normal quantile plot (Figure 6).

To support more flexible modelling of positive values, we use a generalized linear model (GLM) specification, in which we can adopt a non-normal distribution. ${ }^{5}$ The GLM specification requires a definition of the link function $g(\cdot)$ that characterizes how the conditional mean relates to the set of covariates:

$$
g\left(\mu_{i}\right)=\mathbf{X}_{i}^{\prime} \beta \quad \Rightarrow \quad g^{-1}\left(\mathbf{X}_{i}^{\prime} \beta\right)=\mu_{i}
$$

The two most commonly used link functions are the identity link and the log link. With an identity link, the covariates act additively on the mean, and the coefficients are interpreted in the

5. Another way to relax this normality assumption is to use a transformation to normality for the dependent variable, such as the Box-Cox transformation (Jones and Yen 2000; Yen 1993). The GLM specification remains more convenient, because its predictions are on the real scale and do not require a retransformation. To be consistent with the specification used in the subsequent bivariate analysis, we confine ourselves to the use of a non-normal distribution in the GLM framework. 
same way as they would be in OLS, whatever the distribution chosen. In contrast, a log $\operatorname{link}^{6}$ supposes that covariates act multiplicatively on the mean, which changes the interpretation of coefficients:

$$
\ln \left[E\left(y_{i} \mid \mathbf{X}_{i}\right)\right]=\mathbf{X}_{i}^{\prime} \beta \quad \Rightarrow \quad E\left(y_{i} \mid \mathbf{X}_{i}\right)=\exp \left(\mathbf{X}_{i}^{\prime} \beta\right)
$$

There is no single test to identify the appropriate link. Some authors (e.g., Hardin and Hilbe 2012) recommend the use of information statistics, such as log-likelihood, the Akaike information criterion (AIC) or the Bayesian information criterion (BIC), to select the appropriate link. However, these statistics are not stable when the distributional family changes. We prefer different tests of fit instead, namely, the Pregibon (1980) link test, the modified Hosmer and Lemeshow (2000) goodness-of-fit test and the Pearson's correlation test. A particular link function will be selected if all three tests yield non-significant $p$-values. Conversely, if one or more of these tests produces a significant $p$-value, the previous link must be rejected.

The conditional distribution of the positive values should reflect the relationship between the variance and the mean, such that:

$$
\operatorname{Var}\left(y_{i} \mid \mathbf{X}_{i}\right)=\phi E\left(y_{i} \mid \mathbf{X}_{i}\right)^{v}
$$

where $\phi$ is the dispersion parameter and $v$ determines the appropriate distributional family. If $v=0$, the variance is proportional to the mean, so the Gaussian (or normal) family is suitable. If $v=1$, the variance is proportional to the mean that corresponds to the Poisson family. If $v=2$, the variance is proportional to the square of the mean, so the Gamma family will be appropriate. Finally, if $v=3$, the variance is proportional to the cube of the mean, which characterizes the inverse Gaussian or Wald family. To determine the appropriate family distribution, we apply a modified Park test (Manning and Mullahy 2001), based on the $v$ parameter. $^{7}$

6. This differs from log-OLS, which assumes that $E\left[\ln \left(y_{i}\right) \mid \mathbf{X}_{i}\right]=\mathbf{X}_{i}^{\prime} \beta$ and that $E[\ln (y) \mid \mathbf{X}] \neq \ln \left[E\left(y_{i} \mid \mathbf{X}_{i}\right)\right]$.

7. This test consists of regressing $\ln \left[\left(y_{i}-\hat{y}_{i}\right)^{2}\right]$ on $\ln \left(\hat{y}_{i}\right)$ plus a constant. The estimated coefficient then provides an evaluation of the $v$ parameter. 


\subsection{Identification of the causal effect of electrification}

The exogeneity of the electricity dummy is questionable in the literature. Grogan and Sadanand (2013) show that electricity access is endogenous with regard to employment probability, due to the effect of some unobserved factors - such as household wealth or individual taste for work and leisure - on both electricity access and employment probability.

To address this potential bias, we implement a two-stage residual inclusion (2SRI) estimator, as advocated by Terza et al. (2008). The 2SRI estimator is a nonlinear extension of the conventional instrumental variable (IV) method. Instead of replacing the endogenous variable with the firststage predictor in the second stage, as in the conventional IV methods, the 2SRI method includes first-stage residuals as additional regressors in the second stage. First proposed by Hausman (1978) in the linear context, this method proves to be consistent in the class of nonlinear models for which the two-stage predictor substitution is inconsistent (see Terza et al. 2008).

The first-stage equation specifies household electricity access as a function of exogenous variables, including those introduced in the labor supply equations (X) and others that just affect electricity access $(E)$. The first stage consists of a probit model and is specified by a latent variable, $E_{j i}^{*}$, that corresponds to the electricity status $(0,1)$ of household $i$ :

$$
E_{i}^{*}=\mathbf{X}_{i}^{\prime} \delta_{1}+\mathbf{Z}_{i}^{\prime} \delta_{2}+v_{i}, \quad v_{i} \sim \mathcal{N}(0,1)
$$

where $\mathbf{Z}$ is a vector of instrumental variables that correlates with electricity access $(E)$ but not with the residuals $\varepsilon_{i}$ and $u_{I}$, so it can be excluded from the $d_{j i}^{*}$ and $y_{j i}^{*}$ equations. Both properties of $\mathbf{Z}$ must be satisfied to ensure consistent IV estimates. A nonzero correlation between the instruments and the residuals $\varepsilon_{i}$ and $u_{i}$, as well as a weak correlation between the instruments and electricity, can induce inconsistency in the IV estimates that exceeds the inconsistency of naive estimates. We rely on existing literature to select appropriate instruments. The cost differential to extend the electric grid from urban to rural areas may represent an exogenous variation in household electrification. As suggested by Grogan and Sadanand (2013), this variation can be proxied for by the historic population density within the geographical area of interest. Thus, we use the population density in the LGA, derived from the 2006 Census data. ${ }^{8}$ We also consider as a

8. The 2006 Census was the last census in Nigeria. Before 2006, the census data were from 1991. These older data 
potential instrument the distance of the household from the nearest major road. In contrast to the historic population density, we expect a negative effect of this second instrument on household electrification probability. We acknowledge that our instruments are likely to be correlated with unobservable factors that may affect labor supply outcomes. For instance, the local population density might reflect the size of agricultural parcels or it might impact the price of land, and may be correlated by this means with the extent of both farm and non-farm employment. The validity of our identification strategy may nevertheless be ensured by the inclusion of factors reflecting the strength of the local labor market among control variables, i.e. the proportion of the LGA population that resides in urban areas and the unemployment rate in rural areas of the state.

The second-stage equations are then specified as:

$$
\begin{array}{ll}
d_{j i}^{*}=\mathbf{X}_{i}^{\prime} \gamma_{1}+\gamma_{2} v_{i}+\varepsilon_{i}, \quad \varepsilon_{i} \sim \mathcal{N}(0,1), \quad j=h, w, \\
y_{j i}^{*}=\mathbf{X}_{i}^{\prime} \beta_{1}+\beta_{2} v_{i}+u_{i}, \quad u_{i} \sim \mathcal{N}\left(0, \sigma^{2}\right), \quad j=h, w,
\end{array}
$$

where the vector $\mathbf{X}_{i}$ includes the observed electricity access $(E)$ of household $i$, and $v$ is the residual from the first-stage equation. Implementing a significance test on the $\gamma_{2}$ and $\beta_{2}$ coefficients provides a simple and direct way to test the assumption that electricity $(E)$ is exogenous in the participation and time allocation equations, respectively. If $v$ has a significant effect in one or both equations, we can reject the exogeneity assumption of the electricity variable in the corresponding equations.

\subsection{Consideration of dependence between spouses' labor supply decisions}

Following the literature developed by Chiappori $(1988,1992)$ around the conceptual framework of "collective household model", several authors argue that the labor supply decisions of husbands and wives are jointly determined within households (e.g., Huffman and Lange 1989; Zhang 2014). If so, estimating labor supply decisions with ordinary univariate procedures would misrepresent the processes going on at the household level. New insights might be gained by considering labor supply decisions in a two-worker, or husband-wife, model (e.g., Huffman and

cannot be used to compute LGAs' historic population density, given the substantial changes to the states and LGAs since 1991. 
Lange 1989). A joint estimation procedure using a simultaneous equation estimator would increase the statistical efficiency of the parameter estimates, considering that the husband's and wife's labor supply decisions are affected by the same economic shocks and may be made jointly (Mishra and Goodwin 1997; Tokle and Huffman 1991).

We rely on the bivariate hurdle model proposed by Deb et al. (2013) to address the potential dependence between spouses' labor supply within households. This model is particularly attractive; to the best of our knowledge, the joint estimation of hurdle models has not been explored. This model considers four configurations of outcomes; each configuration corresponds to a specific distribution, which is derived from the product of a bivariate hurdle probability and density for the positive outcomes ${ }^{9}$ :

$$
\begin{aligned}
& y_{h}=0, y_{w}=0: \quad F\left(y_{h}=0, y_{w}=0\right), \\
& y_{h}>0, y_{w}=0: \quad F\left(y_{h}>0, y_{w}=0\right) \cdot f_{h}\left(y_{h} \mid y_{h}>0, y_{w}=0\right), \\
& y_{h}=0, y_{w}>0: \quad F\left(y_{h}=0, y_{w}>0\right) \cdot f_{w}\left(y_{w} \mid y_{h}=0, y_{w}>0\right), \\
& y_{h}>0, y_{w}>0: \quad F\left(y_{h}>0, y_{w}>0\right) \cdot f_{h w}\left(y_{h}, y_{w} \mid y_{h}>0, y_{w}>0\right),
\end{aligned}
$$

where $F$ is a bivariate distribution defined over binary labor participation outcomes, $f_{h}$ and $f_{w}$ are univariate densities defined over positive hours of work and $f_{h w}$ is a bivariate density defined over a pair of positive hours of work from both spouses. Deb et al. (2013) initially proposed this model to analyze health expenditures and chose to specify positive values according to the gamma density. Thus, the univariate densities for positive hours of work $\left(f_{h}, f_{w}\right)$ would be defined as:

$$
f_{j}\left(y_{j} \mid y_{j}>0, y_{-j}=0\right)=\frac{\exp \left(-\frac{y_{j}}{\mu_{j}}\right) y_{j}^{\eta_{j}-1}}{\mu_{j}^{\eta_{j}} \Gamma\left(\eta_{j}\right)}, \quad j=h, w ; \mu_{j}>0 ; \eta_{j}>0
$$

where $y_{-j}$ refers to the outcome of the other spouse, $\mu_{j}=\exp \left(\mathbf{X}^{\prime} \beta_{j}\right)$ is the scale parameter,

9. We omit the household subscript $i$ solely to simplify the notation. 
and $\eta_{j}$ is the shape parameter of the gamma distribution.

The desired joint (or bivariate) distributions are generated using a copula-based approach, as pioneered by Sklar (1973). A copula is a function that links a multivariate distribution to its one-dimensional marginal distributions. Here, it implies that for the two dependent variables $y_{h}$ and $y_{w}$, with respective marginal distributions $F_{h}$ and $F_{w}$, there exists a copula $C$ such that

$$
C\left[F_{h}\left(y_{h}\right), F_{w}\left(y_{w}\right) ; \theta\right]=F\left(y_{h}, y_{w}\right)
$$

where $\theta$ is a dependence parameter and $F$ is the joint distribution function of $\left(y_{h}, y_{w}\right)$. Thus, the copula representation $C\left(F\left(y_{h}\right), F\left(y_{w}\right) ; \theta\right)$ can be used in place of the unknown cumulative distribution function (cdf) $F\left(y_{h}, y_{w}\right)$. Several copulas have been proposed, each of which imposes a different dependence structure on the data (e.g., Trivedi and Zimmer 2005). The appropriate copula for a particular application is the one that best captures the dependence features of the data. We rely on the specific class of Archimedean copulas (see Genest and Rivest 1993). These copulas are popular in empirical literature, because they can be stated easily and capture wide ranges of dependence.

Because we have no ex ante knowledge about the dependence structure for our data, we use different copulas: the Frank (1979), the Clayton (1978) and the survival Clayton (SClayton) copula (see Table 12 in Appendix B). The Frank copula is popular because it allows for both negative and positive dependence between marginals, whereas the other two require the dependence parameter to be positive. But this copula allows only weak tail dependance and exhibits the strongest dependence in the middle of the distribution. In contrast, both the Clayton and SClayton copulas allow asymmetric and strong tail dependence. The Clayton copula exhibits strong lower tail dependence and relatively weak upper tail dependence. Thus, it is most appropriate for outcomes that are strongly related at low values but less correlated at high values. Conversely, the SClayton copula would be more suitable for modeling strong upper tail dependence. To examine which of these copulas best fits the data, we rely on the AIC and BIC, as they are usually applied to choose between non-nested parametric models estimated by maximum likelihood.

In the hurdle parts of the model, the marginal distributions are derived using the probit 
formulation, so that

$$
\operatorname{Pr}\left(y_{j}>0\right)=\Phi_{j}\left(\mathbf{X}^{\prime} \beta_{0 j}\right), \quad j=h, w,
$$

where $\mathbf{X}$ is a vector of explanatory variables introduced in each hurdle model, and $\beta_{0 j}$ is the corresponding vector of coefficients to be estimated. The joint probability distribution of positive husband and wife work hours is derived as:

$$
F\left(y_{h}>0, y_{w}>0\right)=C\left(\Phi_{h}(\cdot), \Phi_{w}(\cdot) ; \theta^{0}\right)
$$

where $C$ is the selected copula function, and $\theta^{0}$ is a dependence parameter that captures dependence between the probabilities of any positive outcome. The related probabilities are derived as follows:

$$
\begin{aligned}
& F\left(y_{h}=0, y_{w}=0\right)=1-\Phi_{h}(\cdot)-\Phi_{w}(\cdot)+C\left(\Phi_{h}(\cdot), \Phi_{w}(\cdot) ; \theta^{0}\right) ; \\
& F\left(y_{h}>0, y_{w}=0\right)=\Phi_{h}(\cdot)-C\left(\Phi_{h}(\cdot), \Phi_{w}(\cdot) ; \theta^{0}\right) \text { and } \\
& F\left(y_{h}=0, y_{w}>0\right)=\Phi_{h}(\cdot)-C\left(\Phi_{h}(\cdot), \Phi_{w}(\cdot) ; \theta^{0}\right) .
\end{aligned}
$$

The copula-based joint distribution of positive hours of work is given by:

$$
f_{h w}\left(y_{h}, y_{w} \mid y_{h}>0, y_{w}>0\right)=c\left(F_{h}^{+}(\cdot), F_{w}^{+}(\cdot) ; \theta^{+}\right) \times f_{h}^{+}(\cdot) \times f_{w}^{+}(\cdot),
$$

where $f_{h}^{+}$and $f_{w}^{+}$are the marginal distributions of positive hours of work when both spouses work, defined as:

$$
f_{j}^{+}\left(y_{j} \mid y_{h}>0, y_{w}>0\right)=\frac{\exp \left(-\frac{y_{j}}{\mu_{j}}\right) y_{j}^{\eta_{j}^{+}-1}}{\mu_{j}^{\eta_{j}^{+}} \Gamma\left(\eta_{j}^{+}\right)} \text {for } j=h, w ; \mu_{j}>0 ; \eta_{j}^{+}>0
$$

Here, $c(\cdot)$ is the corresponding copula density, and $F^{+}$is the cumulative distribution function (cdf) version of $f^{+}$. For simplification, we specify $\mu$ to be the same between $f$ and $f^{+}$, but $\eta^{+}$is likely to differ from $\eta$, a prediction we test in the next section. 
The distributional shape of each outcome may differ depending on whether the other outcome equals zero. Also, the dependence parameter $\theta^{+}$between positive outcomes may differ from the dependence parameter $\theta^{0}$.

The joint likelihood forms by using the probability expression for each situation. With the marginal and joint expressions previously defined, the log-likelihood function for the bivariate hurdle model is given by:

$$
\begin{aligned}
\ln L= & \sum_{0,0}\left[\ln \left(F\left(y_{h}=0, y_{w}=0\right), \mathbf{X} ; \theta^{0}\right)\right] \\
& +\sum_{+, 0}\left[\ln \left(F\left(y_{h}>0, y_{w}=0\right), \mathbf{X} ; \theta^{0}\right)+\ln \left(f_{h}(\cdot \mid \mathbf{X})\right)\right] \\
& +\sum_{0,+}\left[\ln \left(F\left(y_{h}=0, y_{w}>0\right), \mathbf{X} ; \theta^{0}\right)+\ln \left(f_{w}(\cdot \mid \mathbf{X})\right)\right] \\
& +\sum_{+,+}\left[\ln \left(F\left(y_{h}>0, y_{w}>0\right), \mathbf{X} ; \theta^{0}\right)+\ln \left(f_{h w}\left(y_{h}, y_{w} \mid y_{h}>0, y_{w}>0, \mathbf{X} ; \theta^{+}\right)\right)\right],
\end{aligned}
$$

where " 0 " indicates summation over the zero observations in the sample, and " + " refers to summation over strictly positive observations. The $\log$-likelihood $\ln L$ is maximized using a Newton-Raphson algorithm with numerical derivatives, implemented using Stata's ml command (lf method).

\section{Results}

We present our empirical results in two broad steps. First, we focus on the independent estimates from the labor supply regressions for wives and husbands, successively. We then analyze the estimates from the bivariate hurdle model and discuss the changes induced by this simultaneous equation approach in comparison with the independent estimates.

In Table 5, we report the specification tests for spouses' positive hours of work. According to the modified Park test, the Poisson is the most appropriate distributional family to model wives' positive hours of work. Both identity and log links may be used to relate the conditional mean of wives' hours of work to the set of covariates, but the $p$-values from the Pregibon and modified Hosmer and Lemeshow tests are higher when we use the log link. The result of the likelihood ratio (LR) test of $\alpha=0$ strongly suggests that the negative binomial model is more 
Table 5. GLM specification tests: link and distribution

\begin{tabular}{|c|c|c|c|c|c|c|c|c|}
\hline \multirow[b]{2}{*}{$\begin{array}{l}\text { Link: } \\
\text { Family: }\end{array}$} & \multicolumn{4}{|c|}{ Wives } & \multicolumn{4}{|c|}{ Husbands } \\
\hline & $\begin{array}{l}\text { Identity } \\
\text { Gaussian }\end{array}$ & $\begin{array}{c}\log \\
\text { Gaussian }\end{array}$ & $\begin{array}{l}\text { Log } \\
\text { NB }\end{array}$ & $\begin{array}{c}\log \\
\text { Gamma }\end{array}$ & $\begin{array}{l}\text { Identity } \\
\text { Gaussian }\end{array}$ & $\begin{array}{c}\text { Log } \\
\text { Gaussian }\end{array}$ & $\begin{array}{l}\log \\
\text { NB }\end{array}$ & $\begin{array}{c}\log \\
\text { Gamma }\end{array}$ \\
\hline \multicolumn{9}{|c|}{ Modified Park test: $\chi^{2}$ (p-value) } \\
\hline$v$ coefficient & 1.073 & 1.052 & 1.119 & 1.119 & 0.345 & 0.310 & 0.377 & 0.377 \\
\hline$v=0:$ Gaussian & $\begin{array}{l}15.458 \\
(0.000)\end{array}$ & $\begin{array}{l}15.110 \\
(0.000)\end{array}$ & $\begin{array}{l}16.523 \\
(0.000)\end{array}$ & $\begin{array}{l}16.531 \\
(0.000)\end{array}$ & $\begin{array}{c}0.997 \\
(0.318)\end{array}$ & $\begin{array}{c}0.847 \\
(0.357)\end{array}$ & $\begin{array}{c}1.137 \\
(0.286)\end{array}$ & $\begin{array}{c}1.139 \\
(0.286)\end{array}$ \\
\hline$v=1:$ Poisson & $\begin{array}{c}0.071 \\
(0.790)\end{array}$ & $\begin{array}{c}0.037 \\
(0.849)\end{array}$ & $\begin{array}{c}0.187 \\
(0.665)\end{array}$ & $\begin{array}{c}0.188 \\
(0.665)\end{array}$ & $\begin{array}{c}3.605 \\
(0.058)\end{array}$ & $\begin{array}{c}4.199 \\
(0.041)\end{array}$ & $\begin{array}{c}3.110 \\
(0.078)\end{array}$ & $\begin{array}{c}3.104 \\
(0.078)\end{array}$ \\
\hline$v=2:$ Gamma & $\begin{array}{l}11.560 \\
(0.001)\end{array}$ & $\begin{array}{l}12.286 \\
(0.001)\end{array}$ & $\begin{array}{l}10.237 \\
(0.001)\end{array}$ & $\begin{array}{l}10.232 \\
(0.001)\end{array}$ & $\begin{array}{l}22.999 \\
(0.000)\end{array}$ & $\begin{array}{l}25.187 \\
(0.000)\end{array}$ & $\begin{array}{l}21.100 \\
(0.000)\end{array}$ & $\begin{array}{l}21.074 \\
(0.000)\end{array}$ \\
\hline$v=3:$ Inverse Gaussian & $\begin{array}{l}49.925 \\
(0.000)\end{array}$ & $\begin{array}{l}51.859 \\
(0.000)\end{array}$ & $\begin{array}{l}46.674 \\
(0.000)\end{array}$ & $\begin{array}{l}46.662 \\
(0.000)\end{array}$ & $\begin{array}{l}59.179 \\
(0.000)\end{array}$ & $\begin{array}{l}63.812 \\
(0.000)\end{array}$ & $\begin{array}{l}55.106 \\
(0.000)\end{array}$ & $\begin{array}{l}55.051 \\
(0.000)\end{array}$ \\
\hline \multicolumn{9}{|l|}{ Tests for link function } \\
\hline Pearson correlation test & 1.000 & 0.907 & 0.922 & 0.923 & 1.000 & 0.890 & 0.863 & 0.863 \\
\hline Pregibon link test & 0.265 & 0.273 & 0.874 & 0.882 & 0.072 & 0.082 & 0.348 & 0.353 \\
\hline Hosmer-Lemishow test & 0.742 & 0.403 & 0.849 & 0.853 & 0.063 & 0.108 & 0.451 & 0.406 \\
\hline \multicolumn{3}{|c|}{$L R$ test of $\alpha=0: \bar{\chi}^{2}$ (p-value $)$} & $\begin{array}{c}4986.14 \\
(0.000)\end{array}$ & & & & $\begin{array}{c}7365.55 \\
(0.000)\end{array}$ & \\
\hline
\end{tabular}

Notes: $\mathrm{NB}=$ negative binomial.

appropriate than the Poisson model, so we only report the other test statistics when using the negative binomial (NB) distribution and ignore those obtained from the Poisson distribution. The test statistics are very similar between the log-link NB distribution and the log-link Gamma distribution. For husbands' positive hours of work, the original double-hurdle model is not adequate; two tests for the link function report significant $p$-values when the normal (or Gaussian) distribution is employed with an identity link. Keeping the same distribution but using a log link is not a fully satisfactory solution: The Pregibon link test still reports a significant $p$-value. Yet the modified Park test first recommends the use of the Gaussian distribution. In addition, the $\chi^{2}$ test reports a weak significant $p$-value for $v=1$, supporting the use of the Poisson distribution. For wives, the LR test of $\alpha=0$ supports the use of the NB distribution rather than the Poisson distribution. When this last distribution is employed with a log link, all tests on the link function report non-significant $p$-values, suggesting a better fit. For the husbands' data, the test statistics again are very close between the log-link NB distribution and log-link Gamma distribution. 


\subsection{Independent estimates of spouses' labor supply}

We gather in Table 6 the main parameter estimates from independent labor supply regressions: for wives on the left side and for husbands on the right side. ${ }^{10}$ At the top of the table, the electricity dummy is assumed to be exogenous in labor supply equations. With this assumption, electricity has no significant effect on wives' labor supply, in terms of either participation or time allocation in the labor market. Despite its frequent use in previous studies, the standard Tobit model is strongly rejected against the double-hurdle model, according to the LR test reported at the bottom of the table. ${ }^{11}$ Thus, the evidence suggests the existence of two separate decisionmaking stages in which wives make independent decisions regarding participation and time allocation in the labor market. According to the tests previously carried out, the NB distribution with a log link is the most suitable specification to model wives' positive hours of work. Using this alternative specification does not change the significance of the parameter estimates. Moreover, the log-link Gamma distribution provides quasi-identical parameter estimates to those obtained with the log-link NB distribution. Thus, whatever the distribution and the link function employed for positive hours of work, electricity has no significant effect on the amount of time that wives allocate to work.

The independent estimates for husbands' labor supply provide the same pattern of results with regard to the electricity coefficient when it is considered exogenous in the corresponding equations. Electricity has no effect on husbands' labor supply outcomes under this assumption. The LR test of the double-hurdle model against the Tobit model strongly rejects the latter specification, but both specifications result in a non-significant effect of electricity on husbands' labor supply. Using more adequate distributions and link function for positive hours of work (i.e., Log NB or Log Gamma) does not change the significance of the parameters in this part of the model.

In the lower part of Table 6, we test the exogeneity of household electrification with regard to spouses' labor supply decisions by implementing the 2SRI estimator described in the previous section. Table 7 contains the parameter estimates from the first-stage Probit models on the prob-

10. The detailed parameter estimates are reported in appendix A, in Table 9 for wives and Table 10 for husbands.

11. Because the standard Tobit model is nested within the double-hurdle model, the LR test is suitable to choose between these specifications. 
Table 6. Electricity and spouses' labor supply: independent estimates

\begin{tabular}{|c|c|c|c|c|c|c|c|c|}
\hline \multirow{3}{*}{ Two-Part Models } & \multicolumn{4}{|c|}{ Wives } & \multicolumn{4}{|c|}{ Husbands } \\
\hline & \multirow{2}{*}{$\begin{array}{l}\text { 1st part } \\
1\left(y_{w}>0\right)\end{array}$} & \multicolumn{3}{|c|}{ 2nd part: $y_{w}$} & \multirow{2}{*}{$\begin{array}{l}\text { 1st part } \\
1\left(y_{h}>0\right)\end{array}$} & \multicolumn{3}{|c|}{ 2nd part: $y_{h}$} \\
\hline & & Normal & $\begin{array}{l}\text { Log } \\
\text { NB }\end{array}$ & $\begin{array}{c}\text { Log } \\
\text { Gamma }\end{array}$ & & Normal & $\begin{array}{l}\text { Log } \\
\text { NB }\end{array}$ & $\begin{array}{c}\text { Log } \\
\text { Gamma }\end{array}$ \\
\hline \multicolumn{9}{|l|}{ Exogenous electricity } \\
\hline electricity & $\begin{array}{r}-0.093 \\
(0.093)\end{array}$ & $\begin{array}{r}-0.088 \\
(1.363)\end{array}$ & $\begin{array}{r}-0.003 \\
(0.029)\end{array}$ & $\begin{array}{l}-0.003 \\
(0.029)\end{array}$ & $\begin{array}{r}0.021 \\
(0.111)\end{array}$ & $\begin{array}{r}0.761 \\
(1.334)\end{array}$ & $\begin{array}{r}0.013 \\
(0.026)\end{array}$ & $\begin{array}{r}0.013 \\
(0.026)\end{array}$ \\
\hline LR test & & $\begin{array}{r}610.689 \\
(0.000)\end{array}$ & & & & $\begin{array}{r}350.805 \\
(0.000)\end{array}$ & & \\
\hline \multicolumn{9}{|c|}{ Endogenous electricity } \\
\hline electricity & $\begin{array}{l}-0.838 \\
(0.690)\end{array}$ & $\begin{array}{r}15.605 \\
(11.753)\end{array}$ & $\begin{array}{l}0.428^{*} \\
(0.246)\end{array}$ & $\begin{array}{l}0.430 * \\
(0.246)\end{array}$ & $\begin{array}{r}0.607 \\
(0.819)\end{array}$ & $\begin{array}{r}20.454^{* *} \\
(9.285)\end{array}$ & $\begin{array}{l}0.395^{* *} \\
(0.186)\end{array}$ & $\begin{array}{l}0.396^{* *} \\
(0.187)\end{array}$ \\
\hline 1st stage residual & $\begin{array}{r}0.310 \\
(0.283)\end{array}$ & $\begin{array}{r}-6.258 \\
(4.860)\end{array}$ & $\begin{array}{l}-0.179 * \\
(0.101)\end{array}$ & $\begin{array}{l}-0.180^{*} \\
(0.101)\end{array}$ & $\begin{array}{r}0.244 \\
(0.334)\end{array}$ & $\begin{array}{r}-8.193^{* *} \\
(3.832)\end{array}$ & $\begin{array}{r}-0.159^{* *} \\
(0.077)\end{array}$ & $\begin{array}{r}-0.159^{* *} \\
(0.078)\end{array}$ \\
\hline LR test & & $\begin{array}{r}613.753 \\
(0.000)\end{array}$ & & & & $\begin{array}{r}350.863 \\
(0.000)\end{array}$ & & \\
\hline $\begin{array}{l}\text { Instrument exclusion: } \\
\text { Wald test } \mathrm{p} \text {-value }\end{array}$ & 0.801 & 0.818 & 0.625 & 0.621 & 0.644 & 0.780 & 0.874 & 0.875 \\
\hline Observations & 1819 & 1298 & 1298 & 1298 & 1819 & 1627 & 1627 & 1627 \\
\hline
\end{tabular}

ability of having electricity. The first-stage regression includes all control variables previously defined, plus an instrument. It is worth noting that the first stage for wives differs from that for husbands. The instrument used for wives, the LGA population density, proves not to be a valid instrument for husbands; it is significantly correlated with husbands' labor outcomes. Conversely, the instrument included in the husbands' first stage, $\mathrm{km}$ to road, is significantly correlated with the residuals in the wives' labor supply equations. Each instrument also has a significant effect on the household's probability of being electrified. The residuals from this first-stage regression are then included as additional regressors in the second-stage equations (1st-stage residual) so that we can directly test the exogeneity of the electricity dummy in these equations.

In the first-part equation for wives (Table 6), the coefficient on the first-stage residual is not significant at conventional levels, so we cannot reject the null hypothesis that electricity is exogenous with respect to wives' employment probability. There is no evidence of uncontrolled factors that significantly affect wives' likelihood of having electricity at home and their employ- 
Table 7. First-stage probit estimates

\begin{tabular}{|c|c|c|c|c|}
\hline & \multicolumn{4}{|c|}{ Dependent variable: electricity } \\
\hline & \multicolumn{2}{|c|}{ Wives } & \multicolumn{2}{|c|}{ Husbands } \\
\hline & Coef. & (Std. Error) & Coef. & (Std. Error) \\
\hline $\operatorname{age}_{w}$ & -0.022 & $(0.024)$ & & - \\
\hline $\operatorname{age}_{w}^{2} / 100$ & 0.031 & $(0.030)$ & & - \\
\hline $\operatorname{educ}_{w}$ & $0.070^{* * *}$ & $(0.010)$ & & - \\
\hline age $_{h}$ & \multicolumn{2}{|c|}{ 一 } & 0.017 & $(0.024)$ \\
\hline $\operatorname{age}_{h}^{2} / 100$ & \multicolumn{2}{|c|}{-} & -0.014 & $(0.024)$ \\
\hline educ $_{h}$ & \multicolumn{2}{|c|}{ - } & $0.063^{* * *}$ & $(0.008)$ \\
\hline muslim & $0.354^{* * *}$ & $(0.131)$ & $0.250^{*}$ & $(0.136)$ \\
\hline kids06 & 0.008 & $(0.029)$ & 0.017 & $(0.029)$ \\
\hline kids612 & -0.012 & $(0.038)$ & -0.032 & $(0.038)$ \\
\hline kids1218 & $0.108^{* *}$ & $(0.043)$ & $0.089^{* *}$ & $(0.042)$ \\
\hline adults & $0.089^{* * *}$ & $(0.035)$ & $0.090^{* * *}$ & $(0.034)$ \\
\hline assets/head & $0.253^{* * *}$ & $(0.034)$ & $0.234^{* * *}$ & $(0.034)$ \\
\hline rural unempl. & -0.865 & (1.756) & -0.598 & $(1.950)$ \\
\hline$\%$ urban & $-0.555^{*}$ & $(0.319)$ & $-0.523^{*}$ & $(0.316)$ \\
\hline constant & $-4.637^{* * *}$ & $(0.650)$ & $-4.624^{* * *}$ & $(0.732)$ \\
\hline \multicolumn{5}{|l|}{ Instruments: } \\
\hline pop. density & $0.125^{* * *}$ & $(0.032)$ & & - \\
\hline $\mathrm{km}$ to road & \multicolumn{2}{|c|}{ - } & $-0.011^{* * *}$ & $(0.003)$ \\
\hline $\ln L$ & \multicolumn{2}{|c|}{-758.658} & \multicolumn{2}{|c|}{-753.432} \\
\hline Observations & \multicolumn{2}{|c|}{1819} & \multicolumn{2}{|c|}{1819} \\
\hline
\end{tabular}

Notes: The data source is the Nigeria 2010-2011 General Household SurveyPanel. Only husbands and wives from monogamous households, aged between 20 and 75 years, are considered. State fixed effects are included in all specifications. Robust standard errors are reported in parentheses. ${ }^{*}, * *$ and ${ }^{* * *}$ indicate significance at $10 \%, 5 \%$ and $1 \%$, respectively.

ment probability. In contrast, this coefficient is significant (and negative) in the hours of work equation, when we employ the log-link NB distribution. Accordingly, we reject the notion that electricity is exogenous with respect to wives' working time, and the estimates in the upper part of Table 6 are downward biased. The negative sign of the coefficient on the first-stage residual implies that there are unobserved factors that affect both wives' likelihood of having electricity and working time, though in opposite directions. Such factors could include individual taste for leisure, which is likely to increase the probability of having electricity but decrease the amount of time devoted to work. Note that the coefficient on the first-stage residual is non-significant in the hours of work equation when the standard normal distribution is used for positive hours in combination with a canonical link function, as in the standard double-hurdle model. This find- 
ing again demonstrates the importance of the econometric specification in assessing the effect of electrification on individual labor supply. When accounting for the endogeneity of the electricity dummy, we find that wives from electrified households have the same probability of working as their counterparts from non-electrified households. But when they work, wives from electrified households devote significantly more time to the labor market than wives from non-electrified households, ceteris paribus. The significance of this effect is rather weak, but its magnitude is substantial. Because we use a log link, we can say that having electricity increases the log mean working time of wives by 0.430 . The exponentiated coefficient is the factor by which the mean outcome from the original scale should be multiplied. In electrified households, the working time of wives is $\exp (0.430)=1.537$ times greater than that in non-electrified households, ceteris paribus.

Using the 2SRI estimator induces more changes in the parameter estimates in the secondpart equation. In the first-part equation, the first-stage residual has no significant coefficient, and its inclusion does not alter the significance of the electricity coefficient. Thus it appears that we reasonably controlled for factors that affect both electrification probability and employment probability. In the second-part equation, the coefficient on the first-stage residual is significant at conventional levels, regardless of the specification used for positive values. The inclusion of this residual thus induces important changes in parameter estimates and specifically in the electricity coefficient, which is now positive and significant at a 5\% significance level. The results for husbands imply that we have failed to control for all the factors affecting the electrification probability and the working time of husbands simultaneously. The negative sign of the coefficient on the first-stage residual suggests that unobserved factors exert opposite effects on these two outcomes, as discussed previously for wives' estimates. The estimates in the left side of Table 10 are thus downward biased. Taking the endogeneity of the electrification status into account allows us to identify a large, positive effect of electrification on the time devoted by working husbands to the labor market. For otherwise comparable characteristics, employed husbands spend substantially more hours at work on average each week when they come from an electrified household. Specifically, employed husbands from electrified households work around 50\% more time than their counterparts from non-electrified households. ${ }^{12}$

12. The working time of husbands in electrified households is $\exp (0.397)=1.486$ times higher than that in non- 
These independent estimates are consistent with existing empirical evidence, in the sense that electrification tends to enhance people's activity in the labor market. But at this stage of the empirical analysis, our results diverge from previous ones and identify a positive effect of electrification on the time allocation decision rather than on the participation decision in the labor market. The singularity of these preliminary results also stands out for the more pronounced effect of electrification on male labor supply than on female labor supply, whereas previous studies emphasized a significant effect primarily on female labor supply. This discrepancy should be interpreted with caution, given the substantial sample selection we have made.

Our observations for monogamous men and their wives are not necessarily true for all men and women. We have decided not to investigate these preliminary results more deeply, because they are based on the questionable assumption that labor supply decisions are independent within the household. Instead, as we discuss in the next section, we test for this assumption.

\subsection{Joint estimates of spouses' labor supply}

\section{Interdependence of spouses' decisions}

As outlined in Section 5.3, our empirical strategy to test independence in labor supply decisions within households is to use a joint estimation procedure for spouses' labor supply outcomes. The simultaneous estimation of hurdle models has not been widely explored in the past, and we rely on the copula-based bivariate hurdle model proposed by Deb et al. (2013). We report in Table 8 the main parameter estimates derived from the bivariate hurdle model, using the three selected copulas.

We focus first on the dependence parameters $\theta^{0}$ and $\theta^{+}$, which measure the dependence of the participation and time allocation outcomes, respectively, after controlling for the effect of all explanatory variables. The significance of each of these dependence parameters, regardless of the copula used, provides evidence that spouses' labor supply outcomes are jointly determined. Thus, this simultaneous equation model should be preferred over the previous independent models. According to these parameters, dependence is positive in both parts of the model, meaning that both employment probability and working time are positively correlated between spouses.

electrified households. 
Table 8. Electricification and spouses' labor supply: bivariate estimates

\begin{tabular}{|c|c|c|c|c|c|c|c|c|}
\hline & \multicolumn{4}{|c|}{ Exogenous electricity } & \multicolumn{4}{|c|}{ Endogenous electricity } \\
\hline & \multicolumn{2}{|c|}{ Hurdle part } & \multicolumn{2}{|c|}{ Positive part } & \multicolumn{2}{|c|}{ Hurdle part } & \multicolumn{2}{|c|}{ Positive part } \\
\hline & $1\left(y_{w}>0\right)$ & $1\left(y_{h}>0\right)$ & $y_{w}$ & $y_{h}$ & $1\left(y_{w}>0\right)$ & $1\left(y_{h}>0\right)$ & $y_{w}$ & $y_{h}$ \\
\hline \multicolumn{9}{|l|}{ Frank copula } \\
\hline electricity & $\begin{array}{l}-0.533 \\
(0.714)\end{array}$ & $\begin{array}{l}-0.585^{*} \\
(0.330)\end{array}$ & $\begin{array}{c}0.011 \\
(0.033)\end{array}$ & $\begin{array}{c}0.043 \\
(0.034)\end{array}$ & $\begin{array}{l}-3.285 \\
(4.659)\end{array}$ & $\begin{array}{l}-0.552 \\
(2.559)\end{array}$ & $\begin{array}{c}0.135 \\
(0.233)\end{array}$ & $\begin{array}{l}0.413^{* *} \\
(0.196)\end{array}$ \\
\hline 1st-stage residual & - & - & - & - & $\begin{array}{l}1.189 \\
(1.977)\end{array}$ & $\begin{array}{l}-0.008 \\
(1.040)\end{array}$ & $\begin{array}{l}-0.052 \\
(0.096)\end{array}$ & $\begin{array}{l}-0.154^{*} \\
(0.081)\end{array}$ \\
\hline$\chi^{2}$ test for $\eta_{j}=\eta_{j}^{+}$ & - & - & $\begin{array}{c}147.81^{* * *} \\
(0.000)\end{array}$ & $\begin{array}{c}130.78^{* * *} \\
(0.000)\end{array}$ & - & - & $\begin{array}{c}148.35^{* * *} \\
(0.000)\end{array}$ & $\begin{array}{c}131.12^{* * *} \\
(0.000)\end{array}$ \\
\hline$\theta^{0} ; \theta^{+}$ & \multicolumn{2}{|c|}{$\begin{array}{l}2.462^{* * *} \\
(0.370)\end{array}$} & \multicolumn{2}{|c|}{$\begin{array}{c}5.872^{* * *} \\
(0.433)\end{array}$} & \multicolumn{2}{|c|}{$\begin{array}{c}2.462^{* * *} \\
(0.370)\end{array}$} & \multicolumn{2}{|c|}{$\begin{array}{c}5.876^{* * *} \\
(0.434)\end{array}$} \\
\hline $\ln L$ & \multicolumn{4}{|c|}{-14203.242} & \multicolumn{4}{|c|}{-14200.686} \\
\hline AIC & \multicolumn{4}{|c|}{28806.263} & \multicolumn{4}{|c|}{28811.036} \\
\hline BIC & \multicolumn{4}{|c|}{29757.571} & \multicolumn{4}{|c|}{29782.483} \\
\hline \multicolumn{9}{|l|}{ Clayton copula } \\
\hline electricity & $\begin{array}{l}-0.668 \\
(0.879)\end{array}$ & $\begin{array}{l}-0.679^{*} \\
(0.367)\end{array}$ & $\begin{array}{c}0.009 \\
(0.030)\end{array}$ & $\begin{array}{c}0.044 \\
(0.027)\end{array}$ & $\begin{array}{l}-5.975 \\
(5.799)\end{array}$ & $\begin{array}{l}-0.703 \\
(3.013)\end{array}$ & $\begin{array}{c}0.231 \\
(0.238)\end{array}$ & $\begin{array}{l}0.397^{*} \\
(0.207)\end{array}$ \\
\hline 1st-stage residual & - & - & - & - & $\begin{array}{c}2.274 \\
(2.454)\end{array}$ & $\begin{array}{c}0.017 \\
(1.221)\end{array}$ & $\begin{array}{l}-0.092 \\
(0.098)\end{array}$ & $\begin{array}{l}-0.147^{*} \\
(0.086)\end{array}$ \\
\hline$\chi^{2}$ test for $\eta_{j}=\eta_{j}^{+}$ & - & - & $\begin{array}{c}257.56^{* * *} \\
(0.000)\end{array}$ & $\begin{array}{l}213.86^{* * *} \\
(0.000)\end{array}$ & - & - & $\begin{array}{c}258.43^{* * *} \\
(0.000)\end{array}$ & $\begin{array}{l}212.78^{* * *} \\
(0.000)\end{array}$ \\
\hline$\theta^{0} ; \theta^{+}$ & \multicolumn{2}{|c|}{$\begin{array}{l}1.311^{* * *} \\
(0.241)\end{array}$} & \multicolumn{2}{|c|}{$\begin{array}{c}0.708^{* * *} \\
(0.099)\end{array}$} & \multicolumn{2}{|c|}{$\begin{array}{l}1.311^{* * *} \\
(0.241)\end{array}$} & \multicolumn{2}{|c|}{$\begin{array}{c}0.706^{* * *} \\
(0.099)\end{array}$} \\
\hline $\ln L$ & \multicolumn{4}{|c|}{-14170.066} & \multicolumn{4}{|c|}{-14167.501} \\
\hline AIC & \multicolumn{4}{|c|}{28739.913} & \multicolumn{4}{|c|}{28744.667} \\
\hline BIC & \multicolumn{4}{|c|}{29691.220} & \multicolumn{4}{|c|}{29716.114} \\
\hline \multicolumn{9}{|l|}{ SClayton copula } \\
\hline electricity & $\begin{array}{l}-0.520 \\
(0.670)\end{array}$ & $\begin{array}{l}-0.565^{*} \\
(0.305)\end{array}$ & $\begin{array}{c}0.022 \\
(0.037)\end{array}$ & $\begin{array}{c}0.043 \\
(0.034)\end{array}$ & $\begin{array}{l}-3.622 \\
(4.249)\end{array}$ & $\begin{array}{l}-0.246 \\
(2.328)\end{array}$ & $\begin{array}{c}0.240 \\
(0.240)\end{array}$ & $\begin{array}{l}0.356^{*} \\
(0.207)\end{array}$ \\
\hline 1st-stage residual & - & - & - & - & $\begin{array}{c}1.328 \\
(1.799)\end{array}$ & $\begin{array}{l}-0.126 \\
(0.938)\end{array}$ & $\begin{array}{l}-0.091 \\
(0.099)\end{array}$ & $\begin{array}{l}-0.130 \\
(0.085)\end{array}$ \\
\hline$\chi^{2}$ test for $\eta_{j}=\eta_{j}^{+}$ & - & - & $\begin{array}{l}112.71^{* * *} \\
(0.000)\end{array}$ & $\begin{array}{c}94.06^{* * *} \\
(0.000)\end{array}$ & - & - & $\begin{array}{c}112.57^{* * *} \\
(0.000)\end{array}$ & $\begin{array}{c}94.04^{* * *} \\
(0.000)\end{array}$ \\
\hline$\theta^{0} ; \theta^{+}$ & \multicolumn{2}{|c|}{$\begin{array}{l}0.336^{* * *} \\
(0.058)\end{array}$} & \multicolumn{2}{|c|}{$\begin{array}{c}1.479^{* * *} \\
(0.197)\end{array}$} & $\begin{array}{r}0.33 \\
(0.0\end{array}$ & $\begin{array}{l}6 * * * \\
58)\end{array}$ & & $\begin{array}{l}8^{* * *} \\
98)\end{array}$ \\
\hline $\ln L$ & & -1428 & .477 & & & -1428 & .416 & \\
\hline AIC & & 2897 & .734 & & & 2897 & 497 & \\
\hline BIC & & 2992 & .041 & & & 2994 & 944 & \\
\hline
\end{tabular}

Notes: The data source is the Nigeria 2010-2011 General Household Survey - Panel. Only husbands and wives from monogamous households, aged between 20 and 75 years, are considered. State fixed effects are included in all specifications. Robust standard errors are reported in parentheses. ${ }^{*}, * *$ and ${ }^{* * *}$ indicate significance at $10 \%, 5 \%$ and $1 \%$, respectively.

Thus, one spouse is more likely to work when the other spouse is working. In addition, when both spouses work, the working time of a spouse correlates positively with the working time of the other: the more the wife works, for example, the more the husband works. These results are quite easy to understand in a context of subsistence agriculture. Indeed, in most households of 
our sample, the activity of both spouses relies on their own family farm production.

On the basis of the information criteria (AIC, BIC), we observe that the Clayton copula better fits the data than the Frank copula, which in turn is more appropriate than the SClayton copula. The better fit of the Clayton copula provides evidence of a strong lower tail dependence and a relatively weak upper tail dependence between labor supply outcomes. Thus, spouses' labor supply outcomes are relatively more strongly related at low values but less correlated at high values. For positive values, this means that the working time of a woman tends to increase with the working time of her husband, essentially for lower values of working time in the sample.

The copula ranking established by the different information criteria is rather consistent; the Frank copula and the SClayton copula better fit data that exhibit weak tail dependence and upper tail dependence, respectively.

Focusing on the parameter estimates from the Clayton copula (see Table 8), we find that the magnitude of dependence is larger in the first part $\left(\theta^{0}=1.311\right)$ than in the second part $\left(\theta^{+}=0.708\right)$ of the bivariate hurdle model, with similar levels of significance. Between spouses, employment probabilities are more closely related than are working times. We also consider whether the working time of a spouse depends on the employment status of the other spouse. We rely on the shape parameters, $\eta_{j}^{+}$and $\eta_{j}$, derived from the Gamma distributions in the respective cases where the other spouse works and does not work. We test the null hypothesis that $\eta_{j}=\eta_{j}^{+}$using a chi-square test. For $j=w$, we actually test whether the distribution of wives' positive hours of work has the same shape, depending on whether or not the husband works. Alternatively, for $j=h$, we test whether the distribution of husbands' positive hours of work is the same depending on whether or not the wife works. We reject the null hypothesis in all specifications; for both husbands and wives, the distribution of positive hours of work varies significantly depending on whether the other spouse works or not.

These assessments apply to both sides of Table 8, that is with or without taking into account the endogeneity of the electrification status. But other parameter estimates vary significantly between the two situations, because electrification status proves to be endogenous with respect to husbands' labor supply. All joint estimation parameters using the Clayton copula are reported in Table 11 in Appendix A. On the left side of the table, with assumed exogenous electricity status, we find that accounting for dependence between spouses' labor supply decisions induces 
significant changes in parameter estimates for the electricity dummy and for the control variables. Focusing on our variable of interest, the bivariate hurdle model reports a weak, significant, negative effect of electricity on the employment probability of husbands, whereas no significant effect emerges from the independent models. In addition, we note a decrease in the significance of the coefficients on some control variables, such as age. Including the previously defined first-stage residual in each equation of the bivariate hurdle model suggests that parameter estimates on the left side are biased. The coefficient on the residual is significant and negative in the $y_{h}$ equation but non-significant in other equations. Thus, the coefficient on the electricity dummy is significant and positive: husbands work more when their dwelling is electrified, ceteris paribus. The significance of this positive effect is smaller than that of the effect estimated previously with the independent model. The bivariate hurdle model induces a greater change in the coefficient on the electricity variable for wives' hours of work. Although the independent estimates suggest that electrification significantly increases the time devoted by wives to the labor market, conditional on them working, this positive effect no longer appears when we control for dependence between spouses.

\section{Implications}

These results contrast with existing evidence in prior literature. Recent studies on developing countries suggest that rural electrification has a positive effect primarily on female employment (e.g., Dinkelman 2011; Grogan and Sadanand 2013) and, more recently, a positive effect on both male and female working time (Dasso and Fernandez 2015). In the previous section (6.1), we find a similar effect of rural electrification on the working time of husbands and wives, when considering the same implicit assumption of independence in labor supply decisions within households. As we remove this restrictive assumption, we show that only husbands' working time is significantly and positively affected by rural electrification in Nigeria. Even if we consider a more restrictive population than previous studies, the significant changes in the effect of electrification when accounting for the dependence between spouses' labor supply decisions suggest the need to take with caution any empirical findings that would ignore this dependence.

From Figure 1, we can explain the positive effect of electrification on husbands' working time mainly through an increase in household time endowment and the resulting reduction in the 
burden of home production. In addition, we can expect that electrification's positive externalities (health improvement, better access to information, empowerment) and its positive effects on market labor demand (business creation, job creation, higher productivity, higher profit) have contributed to this working time increase. When controlling for dependence in spouses' labor supply decisions, we find that wives' labor supply is no longer positively affected by this potentially larger household time endowment.

In line with the household labor supply approach, our findings highlight that, within the household, the labor supply decisions of one spouse significantly affect those of the other spouse. Thus, if we neglect the effect of electrification on the spouse of the individual examined, we may fail to assess how this individual has been actually affected by this common shock on both spouses. Specifically, if one spouse increases her working time following electrification, it is very likely that the corresponding income increase will have a negative effect on the labor supply of the other spouse. Assuming independence in labor supply decisions within the household simply causes this "income effect" to be ignored. In addition, if one spouse increases her working time following electrification, the other spouse will probably have to take charge of the home production previously carried out by the latter, unless the additional time provided by electrification entirely compensates for the extra working time. Our results suggest that these within-household relationships promote husbands' working time at the expense of wives' working time: The larger household time endowment implies an increase in non-market activities (leisure or housework) for wives that compensates its potential positive effect on their labor supply.

Our findings can also be interpreted readily in view of the poor quality of electricity supply in Nigeria, particularly in rural areas. As described in Section 4.2, most rural connected households experience regular blackouts, daily for the majority. In this context, it is difficult to conceive of electricity as a substitute for traditional fuels (e.g., firewood, kerosene). Electricity is more likely to be a complementary form of energy in rural electrified households that still depend on traditional forms of energy. For households to substitute electricity for these more expensive fuels, it would require them to reach a sufficient utilization rate of electrical appliances. Since the current quality of the grid does not allow for that, the state of the supply limits some of the positive effects of electrification on labor supply presented in Figure 1. In particular, electrification is unlikely to induce a significant reduction in the burden of domestic chores and therefore in the 
time that women devote to these chores in rural households. Likewise, the positive externalities of electricity in terms of health and safety may be scarce if it coexists with dirty fuels.

\section{Conclusion}

Using the 2010-2011 GHS, we have investigated the effect of rural electrification on household labor supply in Nigeria. This relationship has been explored recently by a few studies in other developing countries but not, to our knowledge, in Nigeria. Existing studies indicate a positive effect of electrification on individual employment, primarily female employment, and mainly link this effect to an alleviation of time constraints: time saved on domestic chores through the use of electrical appliances, reduced time in collecting fuel, and the extension of the day using artificial lighting. But these studies also suffer some limitations that we propose to address in this paper. First, most previous authors only identify a causal effect on employment probability and tend to ignore the working time dimension. Second, they rely on the strong but questionable assumption that labor supply decisions are independent within the household. To test this assumption, we analyze the labor supply of monogamous married men and women and thus jointly assess changes in their labor supply with electrification. Our econometric strategy depends on the class of hurdle models - also called two-part models - to handle the large number of zero values in weekly hours of work, which serves as our dependent variable. To identify the causal effect, we use instrumental variables, in line with existing literature, namely, the historic population density in the local area and the distance from the household to the nearest major road. A joint estimation of spouses' labor supply outcomes is carried out using the bivariate hurdle model proposed by Deb et al. (2013).

Our empirical analysis shows that electrification increases the time that spouses devote to work, after we control for the endogeneity of electrification status, and this effect varies significantly depending on whether or not the dependence of spouses' labor supply decisions is controlled for. Electrification has no significant effect on spouses' employment probability but increases the working time of both spouses - conditional on them working - when we analyze their labor supply outcomes as independent variables. These intermediate results are in line with existing evidence in the literature (e.g. Dasso and Fernandez 2015). The joint analysis highlights 
that spouses' labor supply decisions are significantly dependent; controlling for this dependence induces a positive effect of electrification only on husbands' working time.

In line with the household labor supply literature (e.g. Chiappori 1988, 1992; Huffman and Lange 1989; Zhang 2014), our findings thus underline that the interdependence of labor supply decisions within the household is critical to consider when assessing the effect of rural electrification on spouses' labor supply. Our results suggest that within households the working time increase of husbands resulting from electrification encourages wives to increase their non-market activities (leisure, housework) while this relationship is neglected in standard independent labor supply estimates. For instance, the husbands' income increase may encourage wives to increase their leisure consumption and decrease their labor supply. In addition, the wives' home production is likely to increase with electrification if the burden of domestic chores does not decrease as much as the market working time of husbands increases. This situation is quite conceivable in rural Nigeria due to the very poor quality of the electricity connection (e.g. frequent blackouts). In this context, electricity is more likely to be a complement to, rather than a substitute for, traditional fuels, and the presumed reduction in domestic work time is likely to be quite small.

This paper provides an initial evaluation of the effect of rural electrification on within-household labor supply decisions in Nigeria and suggests some extensions for further research. First, our results show the importance of taking the dependence of the labor supply decisions between two spouses into account when assessing the impact of electrification on these outcomes. Beyond this husband-wife configuration, it would be useful to explore alternative ways to control for such dependence among a larger set of individuals. In the Nigerian context, studying only monogamous pairs caused us to ignore a large part of the population, such as polygamous households and extended families. If studies could control for dependence among more than two people, it would be possible to consider family configurations in which three or more adults are likely to work. It would also help extend the analysis to child labor, which is rather prevalent in this region. Second, it would be relevant to investigate how rural electrification affects the types of jobs performed by men and women, beyond their total working time. Indeed, we can expect electrification to induce a diversification of activities in rural areas, in particular by encouraging men to work more outside the farm. In addition, focusing on the type of jobs would help to better capture the market work of women, for whom the line between domestic and market work 
is often blurred. Third, in countries like Nigeria, mere connection to the electricity grid proves to be a rather poor measure of the actual use of electricity by the household. Information about the electrical appliances owned by the household and the utilization rate for this equipment might be a more relevant empirical strategy. Finally, as mentioned earlier, the energy sector has experienced significant recent changes, including the privatization of the public firm PHCN and two ambitious governmental plans designed to extend the electrical grid and develop renewable energy resources. In a few years, it would be interesting to investigate how these changes have improved electricity consumption in rural households and their labor supply decisions.

\section{References}

Abdulai, A. and Delgado, C. L. (1999). Determinants of Nonfarm Earnings of Farm-Based Husbands and Wives in Northern Ghana. American Journal of Agricultural Economics, 81(1):117-130.

ADB (2009). Nigeria Economic and Power Sector Reform Program. Appraisal Report. Technical report, African Development Bank Group.

Adenikinju, A. F. (2003). Electric Infrastructure Failures in Nigeria: a Survey-Based Analysis of the Costs and Adjustment Responses. Energy Policy, 31(14):1519-1530.

Ajayi, O. O. and Ajayi, O. O. (2013). Nigeria's Energy Policy: Inferences, Analysis and Legal Ethics Toward RE Development. Energy Policy, 60:61-67.

Akpan, U., Essien, M., and Isihak, S. (2013). The Impact of Rural Electrification on Rural Micro-Enterprises in Niger Delta, Nigeria. Energy for Sustainable Development, 17(5):504-509.

Aliyu, A. S., Ramli, A. T., and Saleh, M. A. (2013). Nigeria Electricity Crisis: Power Generation Capacity Expansion and Environmental Ramifications. Energy, 61:354-367.

Aminu, A. (2010). Determinants of Participation and Earnings in Wage Employment in Nigeria. In 15th IZA/World Bank Conference: Employment and Development, Cape Town, South Africa.

Anugwom, E. E. (2009). Women, Education and Work in Nigeria. Educational Research and Review, 4(4):127134.

Arabmazar, A. and Schmidt, P. (1982). An Investigation of the Robustness of the Tobit Estimator to NonNormality. Econometrica, 50(4):1055-1063. 
Barros, C. P., Ibiowie, A., and Managi, S. (2014). Nigeria's Power Sector: Analysis of Productivity. Economic Analysis and Policy, 44(1):65-73.

Bernard, T. (2010). Etudes d'impact des programmes d'électrification rurale en Afrique subsaharienne. Série Analyse d'impact N³, Agence Française de Développement, Division Évaluation et Capitalisation.

Blundell, R., Ham, J., and Meghir, C. (1987). Unemployment and Female Labour Supply. Economic Journal, 97(388a):44-64.

Bullough, A., Kroeck, K. G., Newburry, W., Kundu, S. K., and Lowe, K. B. (2012). Women's Political Leadership Participation around the World: An Institutional Analysis. Leadership Quarterly, 23(3):398411.

Chiappori, P.-A. (1988). Rational Household Labor Supply. Econometrica, 56(1):63-90.

Chiappori, P.-A. (1992). Collective Labor Supply and Welfare. Journal of Political Economy, 100(3):437-67.

Chowdhury, S. K. (2010). Impact of Infrastructures on Paid Work Opportunities and Unpaid Work Burdens on Rural Women in Bangladesh. Journal of International Development, 22(7):997-1017.

Clayton, D. G. (1978). A Model for Association in Bivariate Life Tables and Its Application in Epidemiological Studies of Familial Tendency in Chronic Disease Incidence. Biometrika, 65(1):141-151.

Cragg, J. G. (1971). Some Statistical Models for Limited Dependent Variables with Application to the Demand for Durable Goods. Econometrica, 39(5):829-844.

Dada, J. O. (2014). Towards Understanding the Benefits and Challenges of Smart/Micro-Grid for Electricity Supply System in Nigeria. Renewable and Sustainable Energy Reviews, 38:1003-1014.

Dahal, S. (2013). Power, Empowerment and Community Radio: Media by and for Women in Nepal. Women's Studies International Forum, 40:44-55.

Dasso, R. and Fernandez, F. (2015). The Effects of Electrification on Employment in Rural Peru. IZA Journal of Labor \& Development, 4(1):1-16.

Deb, P., Trivedi, P. K., and Zimmer, D. M. (2013). Cost-Offsets of Prescription Drug Expenditures: Data Analysis Via a Copula-Based Bivariate Dynamic Hurdle Model. Health Economics, 23(10):1242-1259.

Dinkelman, T. (2011). The Effects of Rural Electrification on Employment: New Evidence from South Africa. American Economic Review, 101(7):3078-3108. 
Duflo, E. (2012). Women Empowerment and Economic Development. Journal of Economic Literature, 50(4):1051-79.

Fadayomi, T. O. and Ogunrinola, I. O. (2013). Determinants of Labor Force Participation in Nigeria: The Influence of Household Structure. Working paper, Covenant University, Department of Economics and Development, Nigeria.

Frank, M. J. (1979). On the Simultaneous Associativity of $F(x, y)$ and $x+y-F(x, y)$. Aequationes Mathematicae, 19(1):194-226.

Genest, C. and Rivest, L.-P. (1993). Statistical Inference Procedures for Bivariate Archimedean Copulas. Journal of the American Statistical Association, 88(423):1034-1043.

Grogan, L. (2012). Household Electrification, Fertility and Employment: Evidence from the Colombian Censuses. Working paper, University of Guelph.

Grogan, L. and Sadanand, A. (2009). Electrification and the Household. Working paper, University of Guelph.

Grogan, L. and Sadanand, A. (2013). Rural Electrification and Employment in Poor Countries: Evidence from Nicaragua. World Development, 43(C):252-265.

Hardin, J. W. and Hilbe, J. W. (2012). Generalized Linear Models and Extensions, 3rd Edition. Stata Press, College Station, TX.

Hausman, J. A. (1978). Specification Tests in Econometrics. Econometrica, 46(6):1251-71.

Heckman, J. J. (1979). Sample Selection Bias as a Specification Error. Econometrica, 47(1):153-161.

Higazi, A. and Brisset-Foucault, F. (2013). Les origines et la transformation de l'insurrection de Boko Haram dans le Nord du Nigeria. Politique africaine, 130(2):137-164.

Hosmer, D. W. and Lemeshow, S. (2000). Applied Logistic Regression. John Wiley \& Sons, New York, 2d edition.

Huffman, W. E. and Lange, M. D. (1989). Off-Farm Work Decisions of Husbands and Wives: Joint Decision Making. Review of Economics and Statistics, 71(3):471-480.

Iyke, B. N. (2015). Electricity Consumption and Economic Growth in Nigeria: A revisit of the EnergyGrowth Debate. Energy Economics, 51:166-176.

Jones, A. M. and Yen, S. T. (2000). A Box-Cox Double-hurdle Model. The Manchester School, 68(2):203-221. 
Kanagawa, M. and Nakata, T. (2008). Assessment of Access to Electricity and the Socio-Economic Impacts in Rural Areas of Developing Countries. Energy Policy, 36(6):2016-2029.

Kohlin, G., Sills, E. O., Pattanayak, S. K., and Wilfong, C. (2011). Energy, Gender and Development: What Are the Linkages? Where is the Evidence? Policy Research Working Paper Series $\mathrm{N}^{\circ} 5800$, The World Bank.

Manning, W. G. and Mullahy, J. (2001). Estimating Log Models: To Transform or Not to Transform? Journal of Health Economics, 20(4):461-494.

Matshe, I. and Young, T. (2004). Off-Farm Labour Allocation Decisions in Small-Scale Rural Households in Zimbabwe. Agricultural Economics, 30(3):175-186.

Mishra, A. K. and Goodwin, B. K. (1997). Farm Income Variability and the Supply of Off-Farm Labor. American Journal of Agricultural Economics, 79(3):880-887.

Ohiare, S. (2015). Expanding Electricity Access to All in Nigeria: a Spatial Planning and Cost Analysis. Energy, Sustainability and Society, 5(1):1-18.

Olatomiwa, L., Mekhilef, S., Huda, A. S. N., and Ohunakin, O. S. (2015). Economic Evaluation of Hybrid Energy Systems for Rural Electrification in Six Geo-political Zones of Nigeria. Renewable Energy, 83:435446.

Oseni, M. O. (2011). An Analysis of the Power Sector Performance in Nigeria. Renewable and Sustainable Energy Reviews, 15(9):4765-4774.

Oseni, M. O. (2012). Households' Access to Electricity and Energy Consumption Pattern in Nigeria. Renewable and Sustainable Energy Reviews, 16(1):990-995.

Ozturk, I. (2010). A Literature Survey on Energy-Growth Nexus. Energy Policy, 38(1):340-349.

Payne, J. E. (2010). A Survey of the Electricity Consumption-Growth Literature. Applied Energy, 87(3):723731.

Pregibon, D. (1980). Goodness of Link Tests for Generalized Linear Models. Journal of the Royal Statistical Society, Series C (Applied Statistics), 29(1):15-23.

Rao, N. D. (2013). Does (Better) Electricity Supply Increase Household Enterprise Income in India? Energy Policy, 57(C):532-541. 
Röllin, H. B., Mathee, A., Bruce, N., Levin, J., and Von Schirnding, Y. E. R. (2004). Comparison of Indoor Air Quality in Electrified and Un-electrified Dwellings in Rural South African Villages. International Journal of Indoor Environment and Health, 14(3):208-216.

Shaaban, M. and Petinrin, J. O. (2014). Renewable Energy Potentials in Nigeria: Meeting Rural Energy Needs. Renewable and Sustainable Energy Reviews, 29:72-84.

Shirazi, F. (2012). Information and Communication Technology and Women Empowerment in Iran. Telematics and Informatics, 29(1):45-55.

Sklar, A. (1973). Random Variables, Joint Distribution Functions, and Copulas. Kybernetika, 9(6):(449)-460.

Skoufias, E. (1994). Using Shadow Wages to Estimate Labor Supply of Agricultural Households. American Journal of Agricultural Economics, 76(2):215-227.

Spalding-Fecher, R. and Matibe, D. K. (2003). Electricity and Externalities in South Africa. Energy Policy, 31(8):721-734.

Terza, J. V., Basu, A., and Rathouz, P. J. (2008). Two-Stage Residual Inclusion Estimation: Addressing Endogeneity in Health Econometric Modeling. Journal of Health Economics, 27(3):531-543.

Tokle, J. G. and Huffman, W. E. (1991). Local Economic Conditions and Wage Labor Decisions of Farm and Rural Nonfarm Couples. American Journal of Agricultural Economics, 73(3):652-670.

Trivedi, P. K. and Zimmer, D. M. (2005). Copula Modeling: An Introduction for Practitioners. Foundations and Trends in Econometrics, 1(1):1-111.

Wooldridge, J. M. (2012). Introductory Econometrics: A Modern Approach. South-Western (Cengage Learning), Mason, 5th edition.

World Bank (2015). World Development Indicators. World Bank, Washington, DC.

Yen, S. T. (1993). Working Wives and Food Away from Home: The Box-Cox Double Hurdle Model. American Journal of Agricultural Economics, 75(4):884-895.

Zhang, S. (2014). Wage Shocks, Household Labor Supply, and Income Instability. Journal of Population Economics, 27(3):767-796. 


\section{Appendices}

\section{A Detailed econometric results}

Table 9. Electricity and wives' labor supply: independent estimates

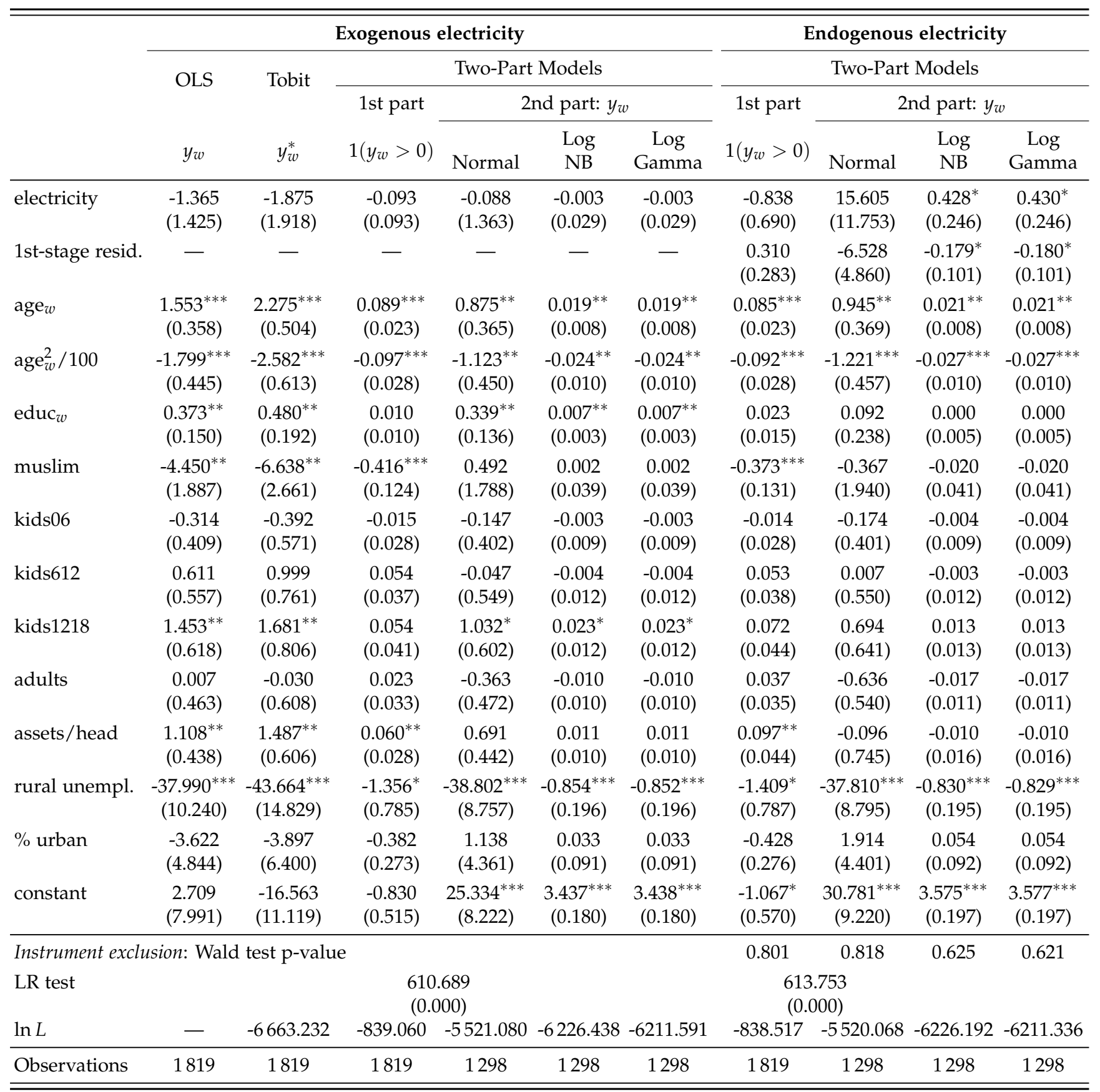

Notes: The data source is the Nigeria 2010-2011 General Household Survey - Panel. Only wives from monogamous households and aged between 20 and 75 years are considered. State fixed effects are included in all specifications. Robust standard errors are reported in parentheses. ${ }^{*} * *$ and ${ }^{* * *}$ indicate significance at $10 \%, 5 \%$ and $1 \%$, respectively. 
Table 10. Electricity and husbands' labor supply: independent estimates

\begin{tabular}{|c|c|c|c|c|c|c|c|c|c|c|}
\hline & \multicolumn{6}{|c|}{ Exogenous electricity } & \multirow{2}{*}{\multicolumn{4}{|c|}{$\begin{array}{c}\text { Endogenous electricity } \\
\text { Two-Part Models }\end{array}$}} \\
\hline & \multirow{3}{*}{$\begin{array}{c}\text { OLS } \\
y_{h}\end{array}$} & \multirow{3}{*}{$\begin{array}{c}\text { Tobit } \\
y_{h}^{*}\end{array}$} & \multicolumn{4}{|c|}{ Two-Part Models } & & & & \\
\hline & & & \multirow{2}{*}{$\begin{array}{l}\text { 1st part } \\
1\left(y_{h}>0\right)\end{array}$} & \multicolumn{3}{|c|}{ 2nd part: $y_{h}$} & \multirow{2}{*}{$\begin{array}{l}\text { 1st part } \\
1\left(y_{h}>0\right)\end{array}$} & \multicolumn{3}{|c|}{ 2nd part: $y_{h}$} \\
\hline & & & & Normal & $\begin{array}{l}\text { Log } \\
\text { NB }\end{array}$ & $\begin{array}{c}\text { Log } \\
\text { Gamma }\end{array}$ & & Normal & $\begin{array}{l}\text { Log } \\
\text { NB }\end{array}$ & $\begin{array}{c}\text { Log } \\
\text { Gamma }\end{array}$ \\
\hline electricity & $\begin{array}{c}0.850 \\
(1.459)\end{array}$ & $\begin{array}{c}0.940 \\
(1.603)\end{array}$ & $\begin{array}{c}0.021 \\
(0.111)\end{array}$ & $\begin{array}{c}0.761 \\
(1.334)\end{array}$ & $\begin{array}{c}0.013 \\
(0.026)\end{array}$ & $\begin{array}{c}0.013 \\
(0.026)\end{array}$ & $\begin{array}{c}0.607 \\
(0.819)\end{array}$ & $\begin{array}{c}20.454^{* *} \\
(9.285)\end{array}$ & $\begin{array}{c}0.395^{* *} \\
(0.186)\end{array}$ & $\begin{array}{c}0.396^{* *} \\
(0.187)\end{array}$ \\
\hline 1st-stage resid. & - & - & - & - & - & - & $\begin{array}{l}-0.244 \\
(0.334)\end{array}$ & $\begin{array}{c}-8.193^{* *} \\
(3.832)\end{array}$ & $\begin{array}{c}-0.159^{* *} \\
(0.077)\end{array}$ & $\begin{array}{c}-0.159^{* *} \\
(0.078)\end{array}$ \\
\hline $\operatorname{age}_{h}$ & $\begin{array}{c}0.956^{* * *} \\
(0.347)\end{array}$ & $\begin{array}{c}1.168^{* * *} \\
(0.394)\end{array}$ & $\begin{array}{c}0.074^{* * *} \\
(0.026)\end{array}$ & $\begin{array}{c}0.363 \\
(0.319)\end{array}$ & $\begin{array}{c}0.006 \\
(0.006)\end{array}$ & $\begin{array}{c}0.006 \\
(0.006)\end{array}$ & $\begin{array}{c}0.071^{* * *} \\
(0.027)\end{array}$ & $\begin{array}{c}0.282 \\
(0.321)\end{array}$ & $\begin{array}{c}0.005 \\
(0.006)\end{array}$ & $\begin{array}{c}0.005 \\
(0.006)\end{array}$ \\
\hline $\operatorname{age}_{h}^{2} / 100$ & $\begin{array}{c}-1.268^{* * *} \\
(0.351)\end{array}$ & $\begin{array}{c}-1.526^{* * *} \\
(0.403)\end{array}$ & $\begin{array}{c}-0.091^{* * *} \\
(0.026)\end{array}$ & $\begin{array}{c}-0.573^{*} \\
(0.325)\end{array}$ & $\begin{array}{l}-0.010 \\
(0.006)\end{array}$ & $\begin{array}{l}-0.010 \\
(0.006)\end{array}$ & $\begin{array}{c}-0.088^{* * *} \\
(0.026)\end{array}$ & $\begin{array}{l}-0.509 \\
(0.326)\end{array}$ & $\begin{array}{l}-0.009 \\
(0.006)\end{array}$ & $\begin{array}{l}-0.009 \\
(0.006)\end{array}$ \\
\hline educ $_{h}$ & $\begin{array}{c}0.150 \\
(0.127)\end{array}$ & $\begin{array}{c}0.122 \\
(0.140)\end{array}$ & $\begin{array}{c}-0.008 \\
(0.010)\end{array}$ & $\begin{array}{c}0.253^{* *} \\
(0.116)\end{array}$ & $\begin{array}{c}0.005^{* *} \\
(0.002)\end{array}$ & $\begin{array}{c}0.005^{* *} \\
(0.002)\end{array}$ & $\begin{array}{l}-0.017 \\
(0.015)\end{array}$ & $\begin{array}{c}-0.037 \\
(0.179)\end{array}$ & $\begin{array}{l}-0.000 \\
(0.003)\end{array}$ & $\begin{array}{l}-0.000 \\
(0.003)\end{array}$ \\
\hline muslim & $\begin{array}{c}6.802^{* * *} \\
(1.999)\end{array}$ & $\begin{array}{c}7.619^{* * *} \\
(2.244)\end{array}$ & $\begin{array}{l}0.323^{*} \\
(0.168)\end{array}$ & $\begin{array}{c}5.145^{* * *} \\
(1.858)\end{array}$ & $\begin{array}{c}0.104^{* * *} \\
(0.037)\end{array}$ & $\begin{array}{c}0.104^{* * *} \\
(0.037)\end{array}$ & $\begin{array}{c}0.282 \\
(0.177)\end{array}$ & $\begin{array}{c}4.122^{* *} \\
(1.857)\end{array}$ & $\begin{array}{c}0.084^{* *} \\
(0.037)\end{array}$ & $\begin{array}{c}0.084^{* *} \\
(0.037)\end{array}$ \\
\hline kids06 & $\begin{array}{l}0.806^{*} \\
(0.436)\end{array}$ & $\begin{array}{c}0.879^{*} \\
(0.478)\end{array}$ & $\begin{array}{c}0.049 \\
(0.035)\end{array}$ & $\begin{array}{c}0.489 \\
(0.407)\end{array}$ & $\begin{array}{c}0.008 \\
(0.008)\end{array}$ & $\begin{array}{c}0.008 \\
(0.008)\end{array}$ & $\begin{array}{c}0.046 \\
(0.035)\end{array}$ & $\begin{array}{c}0.414 \\
(0.407)\end{array}$ & $\begin{array}{c}0.007 \\
(0.008)\end{array}$ & $\begin{array}{c}0.007 \\
(0.008)\end{array}$ \\
\hline kids612 & $\begin{array}{c}0.064 \\
(0.549)\end{array}$ & $\begin{array}{c}0.214 \\
(0.599)\end{array}$ & $\begin{array}{c}0.109^{* *} \\
(0.047)\end{array}$ & $\begin{array}{l}-0.696 \\
(0.510)\end{array}$ & $\begin{array}{l}-0.013 \\
(0.010)\end{array}$ & $\begin{array}{l}-0.013 \\
(0.010)\end{array}$ & $\begin{array}{c}0.113^{* *} \\
(0.048)\end{array}$ & $\begin{array}{l}-0.538 \\
(0.516)\end{array}$ & $\begin{array}{l}-0.010 \\
(0.010)\end{array}$ & $\begin{array}{l}-0.010 \\
(0.010)\end{array}$ \\
\hline kids1218 & $\begin{array}{c}0.437 \\
(0.615)\end{array}$ & $\begin{array}{c}0.487 \\
(0.688)\end{array}$ & $\begin{array}{c}0.005 \\
(0.049)\end{array}$ & $\begin{array}{c}0.405 \\
(0.564)\end{array}$ & $\begin{array}{c}0.009 \\
(0.011)\end{array}$ & $\begin{array}{c}0.009 \\
(0.011)\end{array}$ & $\begin{array}{c}-0.004 \\
(0.050)\end{array}$ & $\begin{array}{c}0.099 \\
(0.580)\end{array}$ & $\begin{array}{c}0.002 \\
(0.011)\end{array}$ & $\begin{array}{c}0.002 \\
(0.011)\end{array}$ \\
\hline adults & $\begin{array}{l}-0.200 \\
(0.513)\end{array}$ & $\begin{array}{l}-0.362 \\
(0.586)\end{array}$ & $\begin{array}{c}-0.064^{*} \\
(0.035)\end{array}$ & $\begin{array}{c}0.522 \\
(0.454)\end{array}$ & $\begin{array}{c}0.007 \\
(0.009)\end{array}$ & $\begin{array}{c}0.007 \\
(0.009)\end{array}$ & $\begin{array}{c}-0.075^{* *} \\
(0.037)\end{array}$ & $\begin{array}{c}0.167 \\
(0.483)\end{array}$ & $\begin{array}{l}-0.000 \\
(0.009)\end{array}$ & $\begin{array}{c}-0.000 \\
(0.009)\end{array}$ \\
\hline assets/head & $\begin{array}{l}0.828^{*} \\
(0.455)\end{array}$ & $\begin{array}{l}0.941^{*} \\
(0.502)\end{array}$ & $\begin{array}{c}0.034 \\
(0.032)\end{array}$ & $\begin{array}{c}0.561 \\
(0.424)\end{array}$ & $\begin{array}{c}0.009 \\
(0.008)\end{array}$ & $\begin{array}{c}0.009 \\
(0.008)\end{array}$ & $\begin{array}{c}0.006 \\
(0.049)\end{array}$ & $\begin{array}{l}-0.367 \\
(0.610)\end{array}$ & $\begin{array}{l}-0.009 \\
(0.012)\end{array}$ & $\begin{array}{l}-0.009 \\
(0.012)\end{array}$ \\
\hline rural unempl. & $\begin{array}{c}-34.390^{* * *} \\
(10.580)\end{array}$ & $\begin{array}{c}-36.359^{* * *} \\
(11.188)\end{array}$ & $\begin{array}{c}0.227 \\
(1.472)\end{array}$ & $\begin{array}{c}-32.233^{* * *} \\
(10.119)\end{array}$ & $\begin{array}{c}-0.616^{* * *} \\
(0.191)\end{array}$ & $\begin{array}{c}-0.615^{* * *} \\
(0.190)\end{array}$ & $\begin{array}{c}0.048 \\
(1.493)\end{array}$ & $\begin{array}{c}-31.515^{* * *} \\
(10.152)\end{array}$ & $\begin{array}{c}-0.599^{* * *} \\
(0.192)\end{array}$ & $\begin{array}{c}-0.599^{* * *} \\
(0.192)\end{array}$ \\
\hline$\%$ urban & $\begin{array}{c}9.902^{* *} \\
(4.394)\end{array}$ & $\begin{array}{c}11.738^{* *} \\
(4.672)\end{array}$ & $\begin{array}{c}0.991^{* *} \\
(0.498)\end{array}$ & $\begin{array}{c}1.980 \\
(4.101)\end{array}$ & $\begin{array}{c}0.048 \\
(0.078)\end{array}$ & $\begin{array}{c}0.048 \\
(0.078)\end{array}$ & $\begin{array}{l}1.021^{* *} \\
(0.503)\end{array}$ & $\begin{array}{c}3.392 \\
(4.129)\end{array}$ & $\begin{array}{c}0.073 \\
(0.078)\end{array}$ & $\begin{array}{c}0.073 \\
(0.078)\end{array}$ \\
\hline constant & $\begin{array}{c}26.080^{* * *} \\
(9.412)\end{array}$ & $\begin{array}{c}20.968^{* *} \\
(10.541) \\
\end{array}$ & $\begin{array}{c}0.193 \\
(0.713) \\
\end{array}$ & $\begin{array}{c}40.900^{* * *} \\
(8.505)\end{array}$ & $\begin{array}{c}3.764^{* * * *} \\
(0.165) \\
\end{array}$ & $\begin{array}{c}3.765^{* * *} \\
(0.165) \\
\end{array}$ & $\begin{array}{c}0.511 \\
(0.854)\end{array}$ & $\begin{array}{c}51.279^{* * *} \\
(9.587) \\
\end{array}$ & $\begin{array}{c}3.962^{* * *} \\
(0.185) \\
\end{array}$ & $\begin{array}{c}3.962^{* * *} \\
(0.185) \\
\end{array}$ \\
\hline Instrument exclu & usion: Wald & test $\mathrm{p}$-value & & & & & 0.644 & 0.780 & 0.874 & 0.875 \\
\hline LR test & & & $\begin{array}{r}350 \\
\quad(0.0\end{array}$ & $\begin{array}{l}.805 \\
000)\end{array}$ & & & $\begin{array}{r}350 \\
\quad(0.0\end{array}$ & $\begin{array}{l}.863 \\
000)\end{array}$ & & \\
\hline $\ln L$ & - & -7785.094 & -506.708 & -7113.645 & -8015.181 & -7998.985 & -506.480 & -7111.672 & -8014.896 & -7998.693 \\
\hline Observations & 1819 & 1819 & 1819 & 1627 & 1627 & 1627 & 1819 & 1627 & 1627 & 1627 \\
\hline
\end{tabular}


Table 11. Bivariate hurdle model with Clayton copula

\begin{tabular}{|c|c|c|c|c|c|c|c|c|}
\hline & \multicolumn{4}{|c|}{ Exogenous electricity } & \multicolumn{4}{|c|}{ Endogenous electricity } \\
\hline & \multicolumn{2}{|c|}{ Hurdle part } & \multicolumn{2}{|c|}{ Positive part } & \multicolumn{2}{|c|}{ Hurdle part } & \multicolumn{2}{|c|}{ Positive part } \\
\hline & $1\left(y_{w}>0\right)$ & $1\left(y_{h}>0\right)$ & $y_{w}$ & $y_{h}$ & $1\left(y_{w}>0\right)$ & $1\left(y_{h}>0\right)$ & $y_{w}$ & $y_{h}$ \\
\hline electricity & $\begin{array}{l}-0.668 \\
(0.879)\end{array}$ & $\begin{array}{c}-0.679^{*} \\
(0.367)\end{array}$ & $\begin{array}{c}0.009 \\
(0.030)\end{array}$ & $\begin{array}{c}0.044 \\
(0.027)\end{array}$ & $\begin{array}{l}-5.975 \\
(5.799)\end{array}$ & $\begin{array}{l}-0.703 \\
(3.013)\end{array}$ & $\begin{array}{c}0.231 \\
(0.238)\end{array}$ & $\begin{array}{l}0.397^{*} \\
(0.207)\end{array}$ \\
\hline 1st-stage residual & - & - & - & - & $\begin{array}{c}2.274 \\
(2.454)\end{array}$ & $\begin{array}{c}0.017 \\
(1.221)\end{array}$ & $\begin{array}{l}-0.092 \\
(0.098)\end{array}$ & $\begin{array}{c}-0.147^{*} \\
(0.086)\end{array}$ \\
\hline $\operatorname{age}_{w}$ & $\begin{array}{l}0.268^{*} \\
(0.143)\end{array}$ & - & $\begin{array}{c}0.011 \\
(0.007)\end{array}$ & - & $\begin{array}{c}0.238 \\
(0.153)\end{array}$ & - & $\begin{array}{c}0.012 \\
(0.008)\end{array}$ & - \\
\hline $\operatorname{age}_{w}^{2} / 100$ & $\begin{array}{c}-0.277 \\
(0.171)\end{array}$ & - & $\begin{array}{l}-0.015 \\
(0.009)\end{array}$ & - & $\begin{array}{l}-0.235 \\
(0.185)\end{array}$ & - & $\begin{array}{c}-0.016^{*} \\
(0.009)\end{array}$ & - \\
\hline $\operatorname{educ}_{w}$ & $\begin{array}{c}0.084 \\
(0.072)\end{array}$ & - & $\begin{array}{l}0.004^{*} \\
(0.003)\end{array}$ & - & $\begin{array}{c}0.180 \\
(0.114)\end{array}$ & - & $\begin{array}{c}0.001 \\
(0.005)\end{array}$ & - \\
\hline age $_{h}$ & - & $\begin{array}{c}0.076 \\
(0.093)\end{array}$ & - & $\begin{array}{c}0.003 \\
(0.006)\end{array}$ & - & $\begin{array}{c}0.076 \\
(0.093)\end{array}$ & - & $\begin{array}{c}0.001 \\
(0.006)\end{array}$ \\
\hline $\operatorname{age}_{h}^{2} / 100$ & - & $\begin{array}{c}-0.053 \\
(0.096)\end{array}$ & - & $\begin{array}{l}-0.007 \\
(0.006)\end{array}$ & - & $\begin{array}{l}-0.054 \\
(0.096)\end{array}$ & - & $\begin{array}{l}-0.006 \\
(0.006)\end{array}$ \\
\hline educ $_{h}$ & - & $\begin{array}{c}0.008 \\
(0.035)\end{array}$ & - & $\begin{array}{c}0.004^{* *} \\
(0.002)\end{array}$ & - & $\begin{array}{c}0.006 \\
(0.052)\end{array}$ & - & $\begin{array}{l}-0.001 \\
(0.004)\end{array}$ \\
\hline muslim & $\begin{array}{c}0.708 \\
(1.534)\end{array}$ & $\begin{array}{c}0.156 \\
(0.548)\end{array}$ & $\begin{array}{l}-0.042 \\
(0.036)\end{array}$ & $\begin{array}{l}0.072^{*} \\
(0.040)\end{array}$ & $\begin{array}{c}0.919 \\
(1.515)\end{array}$ & $\begin{array}{c}0.180 \\
(0.490)\end{array}$ & $\begin{array}{l}-0.054 \\
(0.038)\end{array}$ & $\begin{array}{c}0.052 \\
(0.040)\end{array}$ \\
\hline kids06 & $\begin{array}{c}0.034 \\
(0.202)\end{array}$ & $\begin{array}{c}0.096 \\
(0.134)\end{array}$ & $\begin{array}{l}-0.003 \\
(0.009)\end{array}$ & $\begin{array}{c}0.005 \\
(0.008)\end{array}$ & $\begin{array}{c}0.066 \\
(0.199)\end{array}$ & $\begin{array}{c}0.094 \\
(0.135)\end{array}$ & $\begin{array}{l}-0.004 \\
(0.009)\end{array}$ & $\begin{array}{c}0.004 \\
(0.008)\end{array}$ \\
\hline kids612 & $\begin{array}{l}-0.269 \\
(0.263)\end{array}$ & $\begin{array}{c}0.223 \\
(0.178)\end{array}$ & $\begin{array}{l}-0.009 \\
(0.011)\end{array}$ & $\begin{array}{c}-0.022^{* *} \\
(0.011)\end{array}$ & $\begin{array}{l}-0.251 \\
(0.262)\end{array}$ & $\begin{array}{c}0.220 \\
(0.179)\end{array}$ & $\begin{array}{l}-0.008 \\
(0.011)\end{array}$ & $\begin{array}{c}-0.019^{*} \\
(0.011)\end{array}$ \\
\hline kids1218 & $\begin{array}{c}0.125 \\
(0.378)\end{array}$ & $\begin{array}{c}-0.475^{*} \\
(0.251)\end{array}$ & $\begin{array}{c}0.024^{* *} \\
(0.012)\end{array}$ & $\begin{array}{l}0.022^{* *} \\
(0.011)\end{array}$ & $\begin{array}{c}0.264 \\
(0.418)\end{array}$ & $\begin{array}{c}-0.480^{*} \\
(0.255)\end{array}$ & $\begin{array}{c}0.019 \\
(0.013)\end{array}$ & $\begin{array}{c}0.016 \\
(0.012)\end{array}$ \\
\hline adults & $\begin{array}{c}-0.282^{*} \\
(0.163)\end{array}$ & $\begin{array}{c}0.090 \\
(0.190)\end{array}$ & $\begin{array}{l}-0.009 \\
(0.010)\end{array}$ & $\begin{array}{c}0.003 \\
(0.009)\end{array}$ & $\begin{array}{l}-0.178 \\
(0.207)\end{array}$ & $\begin{array}{c}0.085 \\
(0.198)\end{array}$ & $\begin{array}{l}-0.013 \\
(0.011)\end{array}$ & $\begin{array}{l}-0.003 \\
(0.010)\end{array}$ \\
\hline assets/head & $\begin{array}{c}0.179 \\
(0.325)\end{array}$ & $\begin{array}{c}0.181 \\
(0.118)\end{array}$ & $\begin{array}{c}0.012 \\
(0.009)\end{array}$ & $\begin{array}{c}0.003 \\
(0.009)\end{array}$ & $\begin{array}{c}0.462 \\
(0.456)\end{array}$ & $\begin{array}{c}0.181 \\
(0.206)\end{array}$ & $\begin{array}{c}0.001 \\
(0.014)\end{array}$ & $\begin{array}{c}-0.014 \\
(0.013)\end{array}$ \\
\hline rural unempl. & $\begin{array}{c}3.519 \\
(3.819)\end{array}$ & $\begin{array}{l}-3.646^{*} \\
(1.997)\end{array}$ & $\begin{array}{c}-0.800^{* * *} \\
(0.180)\end{array}$ & $\begin{array}{c}-0.403^{* *} \\
(0.188)\end{array}$ & $\begin{array}{c}5.179 \\
(3.434)\end{array}$ & $\begin{array}{l}-3.604 \\
(2.208)\end{array}$ & $\begin{array}{c}-0.802^{* * *} \\
(0.180)\end{array}$ & $\begin{array}{c}-0.391^{* *} \\
(0.189)\end{array}$ \\
\hline$\%$ urban & $\begin{array}{c}1.368 \\
(.)\end{array}$ & $\begin{array}{l}-0.428 \\
(1.337)\end{array}$ & $\begin{array}{l}-0.023 \\
(0.103)\end{array}$ & $\begin{array}{c}0.078 \\
(0.090)\end{array}$ & $\begin{array}{c}1.557 \\
(.)\end{array}$ & $\begin{array}{l}-0.363 \\
(1.280)\end{array}$ & $\begin{array}{l}-0.013 \\
(0.103)\end{array}$ & $\begin{array}{c}0.099 \\
(0.090)\end{array}$ \\
\hline constant & $\begin{array}{l}-2.915 \\
(3.553)\end{array}$ & $\begin{array}{c}1.543 \\
(2.225)\end{array}$ & $\begin{array}{c}1.896^{* * *} \\
(0.174)\end{array}$ & $\begin{array}{c}2.141^{* * *} \\
(0.173)\end{array}$ & $\begin{array}{l}-5.135 \\
(3.986)\end{array}$ & $\begin{array}{c}1.532 \\
(2.792)\end{array}$ & $\begin{array}{c}1.964^{* * *} \\
(0.184)\end{array}$ & $\begin{array}{c}2.323^{* * *} \\
(0.199)\end{array}$ \\
\hline Observations & 1819 & 1819 & 1298 & 1627 & 1819 & 1819 & 1298 & 1627 \\
\hline
\end{tabular}




\section{B Copula functions}

Table 12. Archimedean copula functions

\begin{tabular}{|c|c|c|c|}
\hline Copula & & $\begin{array}{l}\text { Copula function: } C\left(u_{1}, u_{2}\right) \\
\text { Copula density: } c\left(u_{1}, u_{2}\right)\end{array}$ & $\theta$ interval \\
\hline Frank & $(1)$ & $\begin{array}{c}-\theta^{-1} \log \left[1+\frac{\left(e^{-\theta u_{1}}-1\right)\left(e^{-\theta u_{2}}-1\right)}{e^{-\theta}-1}\right] \\
\frac{\theta\left(1-e^{-\theta}\right) e^{-\theta\left(u_{1}+u_{2}\right)}}{\left[\left(1-e^{-\theta}\right)-\left(1-e^{-\theta u}\right)\left(1-e^{-\theta v}\right)\right]^{2}}\end{array}$ & ]$-\infty, \infty[$ \\
\hline Clayton & (2) & $\begin{array}{l}\left(u_{1}^{-\theta}+u_{2}^{-\theta}-1\right)^{-1 / \theta} \\
(1+\theta) u_{1}^{-1-\theta} u_{2}^{-1-\theta}\left(-1+u_{1}^{-\theta}+u_{2}^{-\theta}\right)^{-2-\frac{1}{\theta}}\end{array}$ & {$[0, \infty[$} \\
\hline SClayton & $\begin{array}{l}(1 \\
(2\end{array}$ & $\begin{array}{l}\left(\left(1-u_{1}\right)^{-\theta}+\left(1-u_{2}\right)^{-\theta}-1\right)^{-1 / \theta}+u_{1}+u_{2}-1 \\
(1+\theta)\left(1-u_{1}\right)^{-1-\theta}\left(1-u_{2}\right)^{-1-\theta}\left[-1+\left(1-u_{1}\right)^{-\theta}+\left(1-u_{2}\right)^{-\theta}\right]^{-2-\frac{1}{\theta}}\end{array}$ & {$[0, \infty[$} \\
\hline
\end{tabular}




\section{Testing the normality assumption of residuals}

Figure 4. Kernel and normal density estimates of residuals
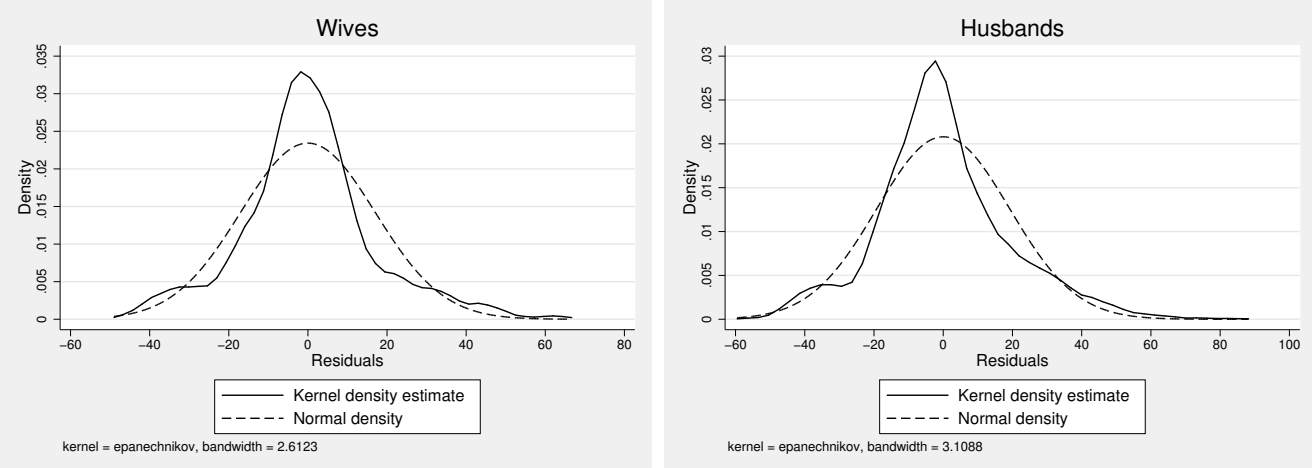

Figure 5. Normal probability plots of residuals
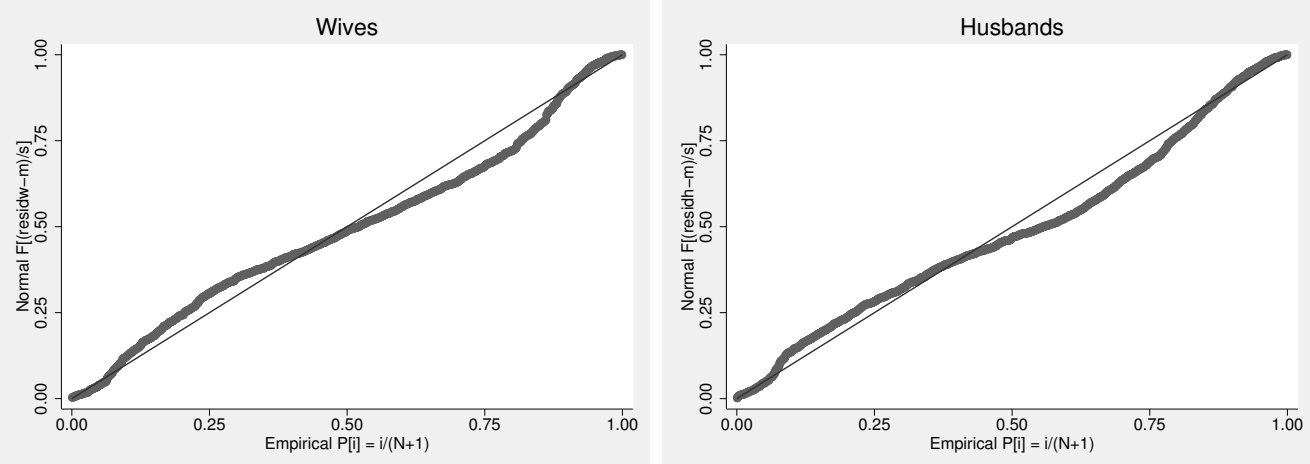

Figure 6. Normal quantile plots of residuals
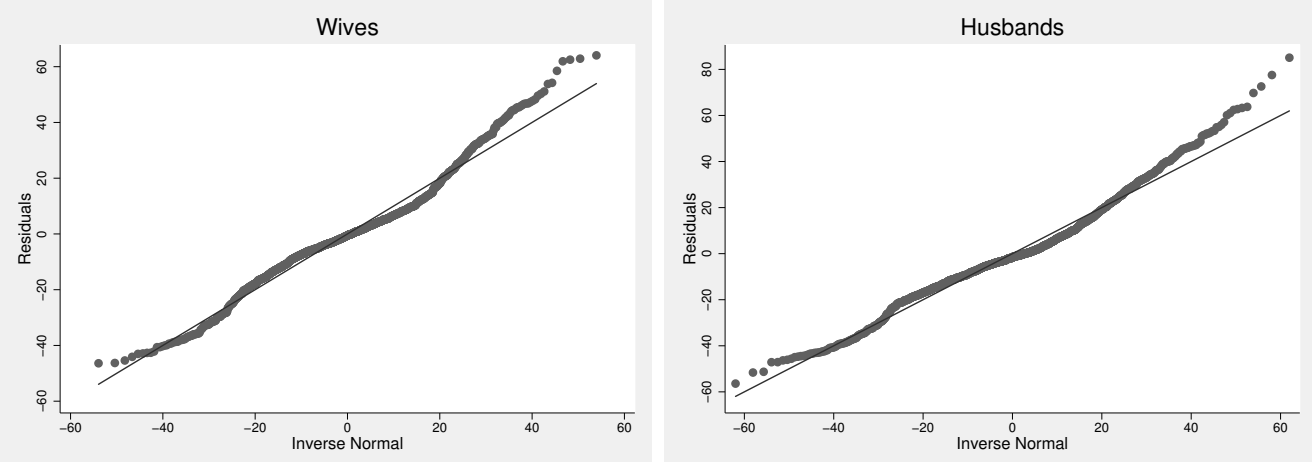


\section{Nigerian states}

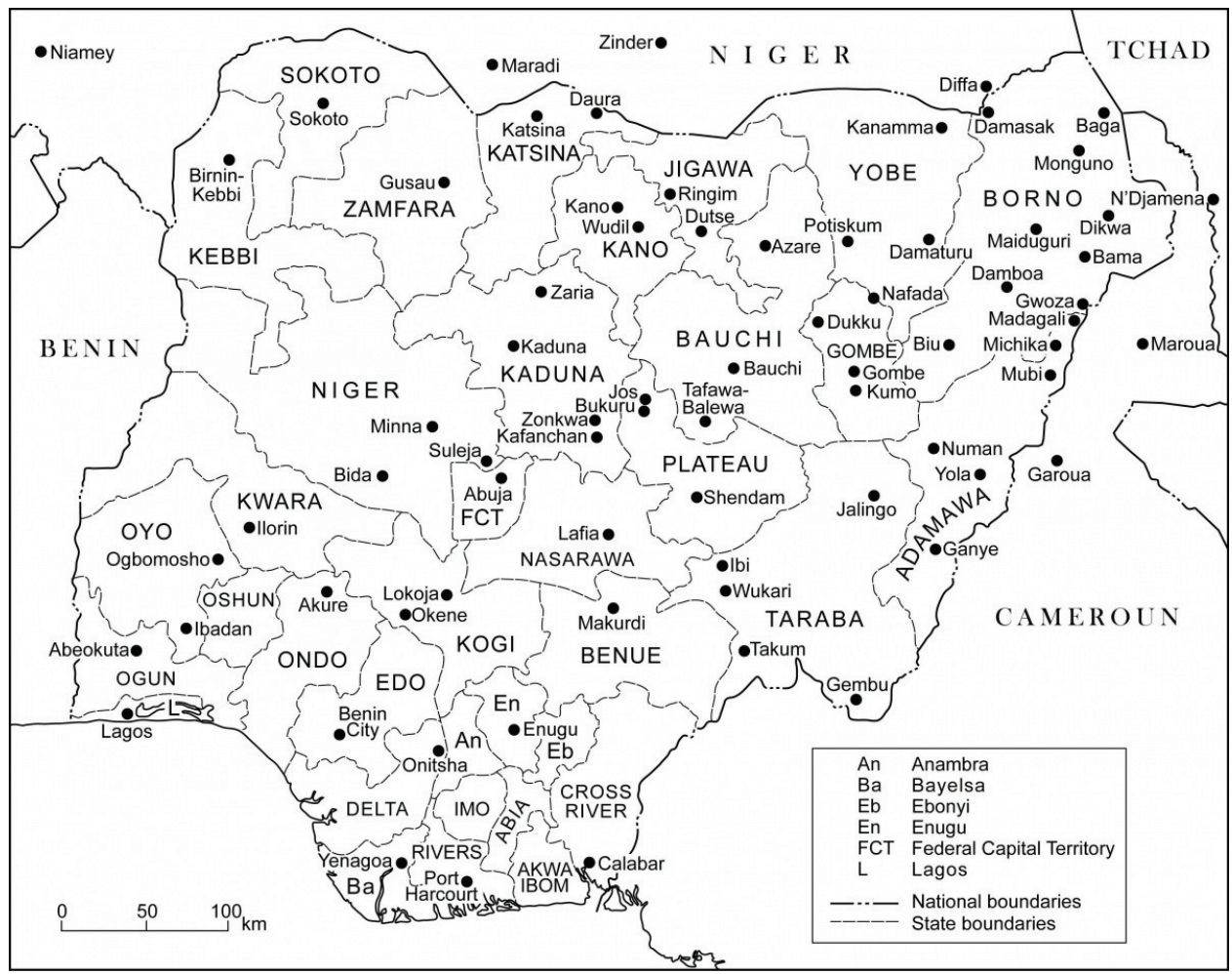

Source: Higazi and Brisset-Foucault (2013) 